
suggestions.

\title{
Evidence About The Link Between Education, Poverty and Terrorism Among Palestinians
}

\author{
Claude Berrebi \\ Princeton University
}

\begin{abstract}
The primary goal of this paper is to investigate whether participation in terrorist activity can be linked to ignorance (measured through schooling) or to economic desperation (measured through poverty on the individual's level and various economic indicators on the societal level) using newly culled data of Hamas and Palestinian Islamic Jihad (PIJ) terrorist cells. This paper performs a statistical analysis of the determinants of participation in Hamas and PIJ terrorist activities in Israel from the late 1980's to the present, as well as a time series analysis of terrorist attacks in Israel with relation to economic conditions. The resulting evidence on the individual level suggests that both higher standards of living and higher levels of education are positively associated with participation in Hamas or PIJ. With regard to the societal economic condition, no sustainable link between terrorism and poverty and education could be found, which I interpret to mean that there is either no link or a very weak indirect link. Special attention is given to the suicide bomber phenomenon, and the analysis of the determinants of becoming a suicide bomber provides additional intriguing findings. In contrast with the "classic" characteristics of a suicidal individual (Hamermesh and Soss, 1974), suicide bombers tend to be of higher economic status and higher educational attainment than their counterparts in the population. Suicide bombers, however, come from lower socioeconomic groups when compared to other, non-suicidal, terrorists.
\end{abstract}

I am grateful to Alan Krueger, Cecilia Rouse, Solomon Polacheck, Jeffery Kling, Esteban Klor, Alexandre Mas, Melissa Clark, Ken Fortson, Yaron Raviv, Erica Field, Gad Levanon, David Linsenmeier, Jane Garrison, Ryan Quillian, and the participants of the Labor seminar for their helpful advice and comments. I thank the Industrial Relations Section for its support, and finally I am indebted to Yaacov Garini and Eman Hassan for excellent translation services. All views expressed and possible errors are solely my own. 


\section{Introduction}

Many people in today's global society, including many of its most prominent leaders and academics, maintain that terrorist activity is the direct result of ignorance and/or poverty. This paper investigates whether terrorism really does have roots in destitution and lack of education. Specifically, I examine correlates of Palestinian terrorist attacks against Israeli targets using micro population data and aggregate time series data. The results of this analysis are surprising and might be perceived as counterintuitive. Common sense might suggest that individuals who have "nothing to lose" (or less to lose) would be more likely to engage in self-destructive activities. Such conventional wisdom could be the result of an intuitive comparison of previous analyses of behaviors with terrorist activity. For instance, one might borrow from the traditional economic theory of crime (Becker, 1968) to analyze terrorist activity, or from the economic theory of suicide (Hamermesh and Soss, 1974) to analyze suicide bombers, or from the economics of religious sects (Berman, 2000) $)^{1}$ to explain participation in secluded terrorist groups. Using these theories in an attempt to explain types of terrorism might misleadingly suggest that, similar to the way that people with fewer opportunities in the legal/outside/secular world would be more likely to commit crimes, commit suicide, or join the religious sects, people with fewer opportunities would likewise tend to join terrorist groups.

Notwithstanding the apparent connection between terrorism and the other economic theories described above, the empirical evidence collected so far gives little reason to believe that materialistic or educational improvements would help reduce terrorism. If anything, the correlation I find is that those with higher education and higher living standards are more likely to participate in terrorist activity. I believe these empirical findings emerge because terrorism is a distinct phenomenon and should be studied as such. It is not yet completely clear how to explain terrorists' motives without assuming irrational, ill or insane decision-making processes, but I am inclined to believe that strong

\footnotetext{
${ }^{1}$ In a recent paper, Berman himself applies a model similar to the one used to explain ultra-orthodox Jews' behavior to the Hamas and Taliban (Berman, 2002).
} 
political motives combined with a subjective perception of injustice, rather than factual economic factors, are at play.

To begin investigating the terrorist mindset, a good place to start is the widespread literature on "hate crimes", a phenomenon that many (e.g., Hamm, 1998 and Kressell, 1996) have considered closely related to terrorism. Green Glaser, and Rich (1998) provide evidence showing that anti-black lynchings and real GNP growth were positively correlated from 1882 to 1938. In addition, data from 1987 to 1995 in New York City shows that hate crimes against blacks, Jews, Asians and homosexuals were unrelated to the city's unemployment rate. Using data about hate crime groups in the United States, Jefferson and Pryor (1999) found that, in 1997, the probability of the existence of such groups, like the Ku Klux Klan, in a particular area was found to be positively associated with the share of the population in that area with at least a high school diploma. The inverse relationship between hate crimes and poverty and/or lack of education is not confined to the U.S., as Krueger and Pischke (1997) found using data from Germany that education and the average manufacturing wage were unrelated to the amount of violence against foreigners.

In addition to the work on hate crimes, a report produced by the Federal Research Division (1999) concerning the sociological characteristics of terrorists in the Cold War period concludes, "Terrorists in general have more than average education, and very few Western terrorists are uneducated or illiterate... Older members and leaders frequently were professionals such as doctors, bankers, lawyers, engineers, journalists, university professors, and mid-level government executives." Once again the trend is not confined by national boundaries, as seen in Russell and Miller (1983), who attempt to draw a sociological profile of the modern urban terrorist based on a compilation and analysis of more than 350 individual terrorists from Argentinean, Brazilian, German, Iranian, Irish, Italian, Japanese, Palestinian, Spanish, Turkish, and Uruguayan terrorist groups active during 1966-76. They found that “... approximately two-thirds of those identified terrorists are persons with some university training, university graduates or postgraduate students." (p.55)

An intriguing publication by Nasra Hassan (2001) already suggested that in the case of terrorism, the traditional models of crime, suicide, and religion might not apply. In an 
article summarizing her interviews of nearly 250 terrorists and associates of terrorists (including failed suicide bombers, families of deceased bombers, and those who trained and prepared the bombers to their missions), she reported, "None of them were uneducated, desperately poor, simple minded or depressed. Many were middle class and, unless they were fugitives, held paying jobs. More than half of them were refugees from what is now Israel. Two were the sons of millionaires."

More recently, people have begun to doubt the intuition that poverty and ignorance are the root causes of terrorism. In an article in the New York Times on the characteristics of the 9/11/2001 terrorist hijackers, 2 Jodi Wilgoren reports that "They were adults with education and skill ... spent years studying and training in the United States, collecting valuable commercial skills and facing many opportunities to change their minds. ... they were not reckless young men facing dire economic conditions and dim prospects but men as old as 41 enjoying middle-class lives." Moreover, if terrorism is regarded as an extreme form of political activism, the inverse relationship with poverty and ignorance should not surprise us. Lerner had already suggested this seemingly contradictory link in 1958 following a study of political activism in the Middle East, where he concluded, "The data obviate the conventional assumption that the Extremists are simply the 'havenots,' suggesting rather that they are the 'want-mores.'” (p.368)

Despite the evidence to the contrary, the commonly held belief continues to be that poverty (of the individuals and society) and ignorance are major factors contributing to the existence of terrorism. Since the tragic events of September 11, 2001, many prominent observers, including the following U.S. officials, have called for increased financial aid and educational assistance to end terrorism by eliminating what is believed to be its core causes.

- President George W. Bush, in a speech on the closing day of a five-day U.N. conference on poverty in Monterey, Mexico on March 22, 2002: "We fight against poverty because hope is an answer to terror...We will challenge the

\footnotetext{
${ }^{2}$ Wilgoren, Jodi. "After the Attacks: The Hijackers; A Terrorist Profile Emerges That Confounds the Experts." New York Times. Saturday, September 15, 2001, late ed.: A2. http://query.nytimes.com/gst/abstract.html?res=F30710F7345C0C768DDDA00894D9404482
} 
poverty and hopelessness and lack of education and failed governments that too often allow conditions that terrorists can seize and try to turn to their advantage.,

- First Lady Laura Bush in a speech to the Organization for Economic Cooperation and Development in Paris on May 15, 2002: "A lasting victory in the war against terror depends on educating the world's children because educated children are much more likely to embrace the values that defeat terror."

- Secretary of State Colin L. Powell in an official US Department of State Document dated February 14, 2002 in Washington, DC: "I fully believe that the root cause of terrorism does come from situations where there is poverty, where there is ignorance, where people see no hope in their lives."B

- Former United States Vice President Al Gore told the Council on Foreign Relations in New York on February 12, 2002 that an 'evil axis' is formed primarily by poverty and ignorance, forcing many to engage in terrorist activities. $^{\text {G }}$

- Deputy Secretary of the Treasury Kenneth Dam on CBSNews in Islamabad, Pakistan on February 5, 2002: "Fighting the root causes of terrorism, poverty, and hopelessness is as important as fighting terrorism directly."

Although some might think that these sentiments have become prevalent only after 9/11, prominent diplomats asserted such opinions prior to 2001. For example:

- Former United States President William J. Clinton in a speech to the Jordanian Parliament in October of 1994, "On one side stand the forces of terror and extremism, who cloak themselves in the rhetoric of religion and nationalism. These forces of reaction feed on disillusionment, poverty and despair."

\footnotetext{
${ }^{3}$ http://www.whitehouse.gov/news/releases/2002/03/20020322-1.html

${ }^{4} \mathrm{http}: / / \mathrm{www}$.jewishsf.com/bk020517/iworld.shtml

${ }_{6}^{5} \mathrm{http}: / / \mathrm{www}$. state.gov/secretary/rm/2002/8038.htm

6 "For there is another Axis of Evil in the world: poverty and ignorance; disease and environmental disorder; corruption and political oppression. We may well put down terror in its present manifestations. But if we do not attend to the larger fundamentals as well, then the ground is fertile and has been seeded for the next generation of those born to hate us..." http://www.al-gore-2004.org/gorespeeches/02122002.htm ${ }^{7} \mathrm{http} / / / \mathrm{www}$. cbsnews.com/stories/2002/02/05/attack/main328279.shtml

${ }^{8} \mathrm{http}: / /$ meria.idc.ac.il/us-policy/data1994.html
} 
- Edward Djerejian, a top US diplomat and former U.S. ambassador to Syria (19881991) and to Israel (1993-1994): "Experience suggests to us that political Islamic movements are to an important degree rooted in worsening socio-economic conditions in individual countries." 2 An excerpt of the Hearing of the Subcommittee on Africa of the House Foreign Affairs Committee on May 12, 1993.

Foreign officials from all over the world seem to hold the same views regarding this linkage:

- British Prime Minister Tony Blair in a speech at the Lord Mayor's banquet, Tuesday, November 13, 2001: “The dragon's teeth [with regards to terrorism and terrorists] are planted in the fertile soil of ... poverty and deprivation."

- Gloria Macapagal-Arroyo, President of the Philippines, on MindaNews, June 12, 2002: "I will be with you, people of Lamitan on the declaration of Independence Day to declare the freedom of the people of Basilan from the bondage of poverty and terrorism." 11

- Prime Minister Ali Abul Ragheb of Jordan in the Jordan Times on Friday and Saturday, September 21-22, 2001: "Elaborating on the causes of terrorism, the prime minister cited political, economic and social conditions, including poverty, ignorance and frustration." 12

- Greek Alternate Foreign Minister Tassos Giannitsis from the Embassy of Greece to the U.S., May 18, 2002: “Terrorism, drugs, poverty and underdevelopment are linked directly and should be jointly handled on a global level."13

- Shimon Peres, former Israeli Prime Minister, at a Briefing to UN Ambassadors and Senior UN Officials at the United Nations in New York on May 30, 1995: "We have to address ourselves to the young generation and to education, so that

\footnotetext{
${ }^{9}$ Congress, House of Representatives, Committee on Foreign Relations, Recommendations for U.S. Foreign Assistance to Africa: Hearing before Subcommittee on Africa before the Committee on Foreign Affairs, $103^{\text {rd }}$ Congress, $1^{\text {st }}$ Session, 12 May 1993, p.91.

${ }^{10} \mathrm{http}: / /$ www.usemb.gov.do/IRC/speeches/Tony_Blair.htm

${ }^{11} \mathrm{http}: / / \mathrm{www} . \mathrm{mindanews.com} / 2002 / 06 / 3 \mathrm{rd} / \mathrm{nws} 12$ indep.html

${ }^{12} \mathrm{http}: / / \mathrm{www}$.jordanembassyus.org/09212001003.htm

${ }^{13} \mathrm{http}: / /$ www.greekembassy.org/press/newsflash/2002/May/nflash0518a.html
} 
neither poverty nor ignorance will continue to feed fundamentalism, poverty, disillusion and hatred., 14

- Terje Roed-Larsen, United Nations special coordinator, according to the August/September 2001 edition of the Washington Report on Middle East Affairs, summed up his speech at the "International Media Encounter on the Question of Palestine" on June $19^{\text {th }}$ by warning that "Poverty breeds hate... and hate creates violence." 15

Many scientists and researchers of the highest ranks hold the same common belief:

- Elie Wiesel, 1986 Nobel Peace Prize recipient, at a gathering of Nobel Peace Prize laureates in Oslo, Norway in December 2001: "Education is the way to eliminate terrorism.,

- Kim Dae-jung, 2000 Nobel Peace Prize recipient and President of South Korea, at a gathering of Nobel Peace Prize laureates in Oslo, Norway in December 2001: "At the bottom of terrorism is poverty. That is the main cause." 17

- Jessica Stern, lecturer on terrorism at Harvard University's Kennedy School of Government and the author of "The Ultimate Terrorists," in a quote from "Being Feared Is Not Enough to Keep Us Safe," which was published in the Washington Post on Saturday, September 15, 2001: "We have a stake in the welfare of other peoples and need to devote a much higher priority to health, education, and economic development, or new Osamas will continue to arise."18

- John O. McGinnis, from the Federalist Society for Law and Public Policy Studies, in a National Security White Paper entitled "Expanding Trade: A Powerful Weapon Against Terrorism": "Ignorance and poverty are the greatest friends of the terrorist, because the ignorant and impoverished are easy prey for the conspiracy theories and millennial religious visions that are the staple of the Islamic fanatics. In contrast, as people become better educated and more

\footnotetext{
${ }^{14}$ http://www.israel-mfa.gov.il/mfa/go.asp?MFAH0chz0

${ }^{15} \mathrm{http} / / / \mathrm{www}$. wrmea.com/archives/august-september01/0108050.html

${ }^{16} \mathrm{http}: / /$ www.csmonitor.com/2001/1210/p7s1-wogi.htm

${ }^{17} \mathrm{http} / / / \mathrm{www}$.parliament.the-stationery-office.co.uk/pa/ld199900/ldhansrd/pdvn/lds02/text/20227-06.htm

${ }^{18} \mathrm{http} / / /$ bcsia.ksg.harvard.edu/publication.cfm?program=ISP\&ctype=article\&item_id=270
} 
prosperous, they will tend to oppose the arbitrary and theocratic rule promised by the terrorists as a threat to their prosperity and freedom." 19

- James Wolfensohn, President of the World Bank, was reported to say, according to the $\mathrm{BBC}$, "that rich countries must build on the global war against terrorism by launching a new war on poverty.",

The need for careful research examining the relationship between poverty, education, and terrorism is clear. The groundwork for such further research began with a recent work by Krueger and Maleckova (2002), who investigate the link between poverty and low education and participation in terrorist activity. Using biographical data of 129 Hizbollah members killed in paramilitary actions in the late 1980's and early 1990's, they found that both having a standard of living above the poverty line and having a secondary-school education or higher are positively associated with participation in Hizbollah. Their paper clearly puts into doubt the supposed benefit of investing in the eradication of poverty or in educational attainment as a means of directly fighting terrorism.

It is important to test whether such results were specific to Hizbollah-Lebanon or whether they can be generalized to other terrorist groups, areas, and time periods. In particular, this paper attempts to verify if such results could be replicated using data relevant to terrorist activities of Hamas and PIJ in Israel and the Palestinian Authority. The data used was collected from biographies of Hamas and PIJ terrorists and population survey data to investigate the link between terrorism and individual income and education. A unique data set that accounts for each and every fatal terrorist incident against Israeli noncombatants together with Palestinian economic variables is used to investigate this link with respect to the society's economic condition.

The paper follows with a discussion of the definition of terrorism I have chosen to work with in the next section. The third section contains a short description of the different terrorist and militant groups involved in the Israeli-Palestinian conflict with an

\footnotetext{
${ }^{19} \mathrm{http} / / /$ www.fed-soc.org/Publications/Terrorism/trade.htm

${ }^{20} \mathrm{http}: / /$ news.bbc.co.uk/1/hi/business/1857642.stm
} 
emphasis on the Hamas and PIJ because of their centrality to my research. The fourth section will provide some theoretical considerations concerning the relationship between education and income and terrorism. A description of the data I used in the different analyses makes up section five. The sixth section describes the statistical analysis used to measure the correlates of participation in Hamas and PIJ terrorist activities and the time series analysis used to estimate the relationship between economic variables and terrorist attacks. The results of the study are presented in section seven and section eight concludes the paper. 


\section{Definition of Terrorism}

Definitions of terrorism vary widely, and it is therefore difficult, if not impossible, to find a single definition that covers all aspects of terrorism as they exist in today's world. A certain event can be defined as an act of terror in the views of one country and at the same time be defined as a "fight for freedom" by another.

The FBI defines terrorism as "the unlawful use of force or violence against persons or property to intimidate or coerce a Government, the civilian population, or any segment thereof, in furtherance of political or social objectives." ${ }^{21}$ Deluxe Black's Law Dictionary defines an act of terrorism as "An activity that involves a violent act or an act dangerous to human life that is a violation of the criminal laws... and appears to be intended - (i) to intimidate or coerce a civilian population; (ii) to influence the policy of a government by intimidation or coercion, or (iii) to affect the conduct of a government by assassination or kidnapping.",22

While the above definitions encompass a wide range of terrorism, I have chosen to use the definition used by the US State Department, which is contained in Title 22 of the United States Code, Section 2656f(d):

- The term 'terrorism' means premeditated, politically motivated violence perpetrated against noncombatant (1) targets by subnational groups or clandestine agents, usually intended to influence an audience.

- The term 'international terrorism' means terrorism involving citizens or the territory of more than one country.

- The term 'terrorist group' means any group practicing, or that has significant subgroups that practice, international terrorism.

(1) For purposes of this definition, the term "noncombatant" is interpreted to include, in addition to civilians, military personnel who at the time of the incident are unarmed and/or not on duty...We also consider as acts of terrorism attacks on military installations or on armed military personnel when a state of military hostilities does not exist at the site.

\footnotetext{
${ }^{21}$ Federal Bureau of Investigation. "Thirty Years of Terror: A Retrospective Edition.” Terrorism in the United States 1999. p. i. http://www.fbi.gov/publications/terror/terror99.pdf

${ }^{22}$ Black's Law Dictionary, 6th Edition, p. 1473.

${ }^{23}$ The U.S. government has employed this definition of terrorism for statistical and analytical purposes since 1983. http://www.state.gov/s/ct/rls/pgtrpt/2000/2419.htm
} 
It is important to keep in mind that I have chosen to rely on the US State Department definition of terrorism in order to exploit the fact that the US State Department has already categorized and specified the set of contemporary terrorist groups (Hamas and PIJ are currently designated by the US Secretary of State as Foreign Terrorist Organizations-FTOs). However, using any other definition that regards terrorist action as the calculated use of unexpected, shocking, and unlawful violence against noncombatants (including, in addition to civilians, off-duty military and security personnel) and other symbolic targets perpetrated by a clandestine member(s) of a subnational group or a clandestine agent(s) for the psychological purpose of publicizing a political or religious cause and/or intimidating or coercing a government(s) or civilian population into accepting demands on behalf of the cause $\mathrm{e}^{24}$ would not change any of the analysis since it would unarguably label Hamas and PIJ militant activities as terrorist activities. It is important to remember that in this paper, the nouns "terrorist" or "terrorists" do not necessarily refer to everyone within a terrorist organization, but to activists or operators who personally carry out a group's terrorism strategy and their leaders.

\footnotetext{
${ }^{24}$ This definition was borrowed from: Rex A. Hudson, "The Sociology and Psychology of Terrorism: Who
} Becomes a Terrorist and Why?" Federal Research Division, Library of Congress, September 1999. 


\section{Background}

The historical background and evolution of terrorist activities in the Middle East is complex, controversial, and, although important, is outside the scope of this paper and should be the subject of additional research. Instead of being an exhaustive study in the history of Middle Eastern terrorist organizations, the goal of this section is to expose the different contemporary militant/terrorist forces in the Israeli-Palestinian region.

Al-Fatah is a reverse acronym for "Harekat at-Tahrir al-Wataniyyeh alFalastiniyyeh" and translates to mean "an organization for liberation of Palestine," and the word "Fatah" itself means "conquest with jihad." Established by Yasser Arafat circa 1960, Al-Fatah joined the PLO in 1968 and gained control in 1969. The group was based in Jordan until 1970 when it was expelled to Lebanon, and then moved again to Tunisia in 1982. The organization was active in numerous terrorist activities in the 1970's and 1980's, but ceased these activities following the Oslo Agreement in 1993. Al-Fatah has three affiliates still carrying out terrorist activities: Al-Aqsa Martyr Brigades, Tanzim, and Force 17.

Al-Aqsa Martyrs Brigade was named after the Al-Aqsa Mosque in Jerusalem. The group, consisting of terrorists from the West Bank, is affiliated with Al-Fatah and was established at the beginning of the $2^{\text {nd }}$ Intifada in September of 2000. The Martyrs Brigade is responsible for numerous terror activities including suicide bombing, sniper attacks, knife stabs and more. Al-Aqsa Martyrs Brigade has so far taken responsibility for the deaths of more than 100 Israeli civilians and the injuries of thousands.

Tanzim, which means "Organization," is an armed wing of Al-Fatah and was established in 1995. The group acts to balance the activity of the extreme groups, such as Hamas and PIJ, and has served as a driving force behind a number of riots, including the $2^{\text {nd }}$ Intifada. Among its terrorist activities are the ambushing of vehicles, shootings, and bus bombings. The Tanzim consists of tens of thousands of members, spread throughout the West Bank and Gaza Strip, and is funded by the Palestinian Authority. The head of the Tanzim is Marwan Bargouti, who now stands trial in Israel for various acts of terror.

\footnotetext{
${ }^{25}$ In addition to the background provided here, it might be useful to be acquainted with the Palestinian security forces and structure as described in Appendices C and D.
} 
Tanzim is responsible for the deaths of approximately 30 Israeli civilians and the injuries of a few hundred.

Force 17 is the personal security force for Yasser Arafat that was established in the early 1970's and is funded by the PLO. It is a high quality, well-trained unit consisting of approximately 3,000 members, led by Faisal Abu Sharah, with a long history of terrorist activities against Israeli targets. The unit's first commander, Ali Hassan Salameh, took part in the 1972 Olympics massacre of the Israeli delegation. Force 17 is responsible for the deaths of more than 10 Israeli civilians in terror activities.

Popular Front for the Liberation of Palestine (PFLP) - Formed by George Habash in 1967, the PFLP saw the elimination of Israel as facilitating the development of communism in the Middle East. The PFLP was an original member of the PLO, but opposed the PLO's negotiations with Israel. The PFLP is responsible for the deaths of more than 100 Israeli civilians.

Popular Front for the Liberation of Palestine - General Command (PFLP -GC) The PFLP-GC split from the PFLP in 1968 under the leadership of their founder, Ahmad Za'rur. Currently led by Ahmad Jibril, they continue to reject any kind of recognition of and negotiation with Israel and are responsible for the deaths of more than 50 Israeli civilians.

Democratic Front for the Liberation of Palestine (DFLP) - The DFLP split from the PFLP in 1969 and supports the creation of a Palestinian state in any territory liberated from Israel. They are responsible for the deaths of more than 35 Israeli civilians.

Hizbollah - This radical Shiite group that was formed and operated in Lebanon, which at times infiltrates the Israeli-Lebanese border, receives funding, weapons, explosives, and recruits from Iran. Their force includes a few hundred operatives and a few thousand supporters. Hizbollah was responsible for more than 300 deaths and more than 500 injuries through its terror activities.

Abu Nidal Organization (ANO) - Sponsored by Iraq, Syria and Libya, the ANO advocates the destruction of Israel and uses is force of a few hundred operatives in an attempt to attain that goal. Although the ANO's activities were critically reduced after the mysterious death of Abu Nidal in August 2002, they have been responsible for approximately 300 deaths and the wounding of hundreds more. 


\section{Hamas}

Hamas, a word meaning 'courage' and 'bravery,' is a short form in Arabic for "Harakat al-Muqawamah al-Islamiyya" - meaning "the Islamic resistance movement." Hamas is a radical Islamic organization based in the West Bank and Gaza Strip that first registered as a non-profit organization in 1978 led by Sheik Ahmad Yassin under the influence of the Muslim Brotherhood, which was established in the 1920s in Egypt with the purpose of an Islamic "revival". When initiating its activity, Hamas' activities mainly involved religious propaganda and social work through financing coming primarily from Islamic supporters around the world.

When the $1^{\text {st }}$ Intifada broke in December of 1987, Hamas gained momentum along with the Intifada and expanded its activities by introducing a militant faction of the organization. Hamas declared Jihad (holy war) against Israel, with the stated purpose of destroying Israel and creating a Palestinian state between the Mediterranean Sea and the Jordan River. In pursuit of that goal, Hamas shifted the weight of its activities towards militancy, and today the overwhelming majority of Hamas' activities are militant.

In 1991, Hamas established the Iz al-Din Al Kassam brigades, which control the military and terrorist activities including intelligence, recruitment, and training. These brigades have a network of small cells that do not communicate with each other, so the fall of one cell will not cause the fall of others. The total estimated number of hard-core operatives is less than 400 .

Hamas leadership includes its founder and spiritual leader, Sheik Ahmad Yassin, and its two spokesmen, Dr. Abdel Aziz Rantisi and Abdul Haleq Natsheh. Militant leaders are less likely to be publicly known, but among the known ones are Hassan Yusuf and Mohammad Deif. Some of Hamas' leaders who carried out numerous deadly terror activities against Israelis were targeted for extra-judicial execution by Israel, including Yahya Ayyash and Salah Shehada. The organization has strong financial support from three main sources: (1) unofficial bodies in Muslim countries, mostly in and around Saudi Arabia; (2) Iran; and (3) charity networks in the West Bank, Gaza Strip, and abroad.

Hamas stepped up its terrorist activities in stages. Initially, Hamas was only involved in disturbances and strikes, then it began the assassination of what it defined as 
"collaborators with Israel." It moved on to kidnapping and killing Israeli soldiers, then to knife attacks against soldiers and civilians, and finally to shootings, bombings, and suicide attacks in every place Israelis could be reached. Hamas took responsibility for the deaths of more than 500 Israeli civilians and soldiers in addition to thousands of injuries. Since Hamas' activities are defined as Jihad, the group does not differentiate between soldiers and civilians, young and old—everything is justified by the cause.

\section{Palestinian Islamic Jihad (PIJ)}

Although there are many, the Palestinian Islamic Jihad (PIJ) is the most well known extremist group using the name Islamic Jihad. The PIJ calls for an armed Islamic war against Israel in order to free Palestine and create an Islamic state instead of Israel. Palestinian Islamic Jihad is a translation from Arabic for "Harakat al-Jihad al-Islami alFilastini," which means "Movement for holy war to Palestine."

Students, inspired by the Iranian revolution and militant Islamic Egyptian organizations, founded the PIJ around 1980 in Egypt and were led by one of the founders, Fathi Shkaki. The PIJ was active mainly in the West Bank and Gaza Strip, and initially put emphasis on Islamic culture, postponing the Palestinian issue. In the 1980's, the PIJ started its disruptive activities, and moved on to terrorist activities that included a number of attacks in the Gaza Strip in 1987 prior to the start of the Intifada in December. As the PIJ increased its terrorist activities, two of its leaders - Shkaki and Abdul Aziz Odeh were expelled to Lebanon in August of 1988, but Shkaki reorganized the group from there, where he also tightened the connections with Iran, PIJ's main supporter. In addition to the financial funding from Iran, the PIJ also receives logistic assistance from Syria.

The PIJ and Hamas were violent rivals until the establishment of the Palestinian Authority in 1994, which began a period of relatively peaceful coexistence as they both terrorized Israel. Both organizations took responsibility for some of the worst terrorist acts and as a result, the PIJ gained skill, experience, and support from the Palestinian public. Shkaki was killed in 1995 in Malta, supposedly by Israeli agents, and he was succeeded by Dr. Ramadan Abdullah Shalah, who resides in Damascus. Shkaki's death damaged the PIJ's position in Gaza Strip and the West Bank, and Hamas no longer sees it 
as a threatening rival. During its existence, the PIJ has claimed responsibility for over 140 Israeli deaths and more than 1,000 injuries. 


\section{Theoretical considerations:}

Traditional economic considerations following Becker (1968) suggest that people with higher education and higher income have more at stake (or more to lose) from taking part in criminal activities. Such individuals, when choosing how to allocate their time between legal and illegal activities to maximize their utility, will presumably find better (and less risky) alternatives and would therefore have fewer reasons to join restrictive groups. A simplified summary of the equilibrium described in Berman (2002) would suggest that high wage individuals are less likely to be impressed by "club goods" $" 26$ and are therefore less likely to make sacrifices to join exclusive organizations. Furthermore, increased knowledge (a probable result of additional education) may provide better reasoning skills, which might deter potential terrorists from engaging in militant activities.

Many other considerations have been given to support this conventional wisdom and I do not pretend that I have described most of the main arguments and theories supporting it. However, if terrorism is considered as a distinct phenomenon rather than considering it a branch of criminal activity, there is little in economic theory to conclusively prove a positive correlation exists between terrorist behavior and low education or income. In fact, economic theory does not stipulate whether education and income are even linked to terrorist activities.

Despite the lack of a proven association between education, economic status, and terrorism, there are many reasons that could cause highly educated and wealthy individuals to engage in terrorist activities. Educational content (particularly that which advocates particular political or religious messages) may exacerbate existing tensions and increased exposure to such content (in the form of additional education) may increase an individual's propensity to participate in terrorist organizations. That aside, improving reasoning skills may lead to involvement in terrorist organizations because individuals with more education may be better equipped to understand moral and religious justifications invoked by such groups. Further, highly educated individuals may be more aware of situations of injustice and discrimination, and may be more aggravated by their

26 "Club goods" are special perks that only members of a particular group enjoy. 
implications, again inducing them to participate in terrorist activities. Similarly, education may contribute to the development of a sense of social responsibility and highly educated individuals may feel the need to contribute to particular causes. If an individual is a proponent of a belief that is primarily advocated via terrorism, he may be more likely to become an active participant in terrorist activities.

In addition to the preceding argument, highly educated individuals may care more about preserving image and could be more easily swayed by public opinion in their behavior, which may lead such individuals to engage in terrorist activities if terrorism enjoys popular support. Moreover, individuals initially interested in joining terrorist organizations might be more likely to get more education in an attempt to become an active terrorist. If education improves performance in terrorist organizations, an individual with militant tendencies might acquire more education in order to be more successful in such activities. Because terrorism might require additional education, one cannot a priori dismiss the possibility that terrorism is in fact a high-skill occupation.

Terrorism may also be a means of achieving success for individuals with limited opportunities elsewhere. Therefore, terrorist organizations might attract highly successful (and, most likely, highly educated) individuals that are otherwise well qualified but cannot succeed in the non-terrorism marketplace because of their heritage, social standing, etc. (this would especially be true in non-democratic societies). It is also possible that terrorist organizations are faced with an excessive supply of potential participants and can therefore choose the select few they desire. Consequently, it may be that the potential terrorists selected by these groups are highly-educated even though, on average, the education of those willing to join such organizations may be no greater than average.

Likewise, wealth may also increase the likelihood that an individual will participate in terrorist activities. For example, terrorism may require a certain degree of wealth because capital provides the means to carrying out acts of terror. Weapons must be acquired on the black market, which is extremely expensive (and could preclude poor individuals from participating) due to the limited access to warfare equipment in areas where terrorism is prevalent as a result of the presence of official police and army forces. In addition, wealthy individuals may be more likely to encounter barriers and restrictions 
in daily life (that poorer individuals might not come across) because of the opportunities that wealth provides (e.g., in governmental paperwork, access to financial markets, and commercial spheres). By being exposed to such restrictions, wealthy individuals may be more likely to become enraged by certain organizations or groups, and, therefore, may be more likely to engage in terrorist activities. Moreover, it is plausible that relatively poorer individuals are more preoccupied with daily matters, such as providing for their families, and end up devoting less attention to militant struggles.

To conclude, it cannot be dismissed that wealthy and educated individuals would necessarily be averse to participation in terrorist activity. In fact, there is nothing in economic theory that is a priori inconsistent with evidence showing that high-education, high-income individuals are more likely to participate in terrorist activities. 


\section{Data and Sample:}

\section{Terrorists’ Biographical Data and its Counterfactual Population Survey Data}

In my research, I have been able to translate and collect information from the biographies of 335 Palestinian Terrorists. To find the data, I tracked down "Shahid" (deceased "martyrs") publications from websites and Online Journals of the Hamas, Palestinian Islamic Jihad (PIJ), and the Palestinian National Authority (PNA) 27 . In addition, I have used a PIJ publication containing the biographies of 50 PIJ leaders that were part of a group of 417 leaders and foot soldiers of terror groups that were expelled to Lebanon by Israel on December 17, 1992. Altogether, the data consists of observations taken from the available biographies with the following breakdown:

\section{3 "Shahids" of the Hamas; \\ 103 "Shahids" of the PIJ, one of who was also a Hamas member; 50 leaders of the PIJ;}

In 319 of the 335 cases, the date of the biography could be determined either because it corresponded to the date of death of the "Shahid", or because the terrorist was expelled to Lebanon on a known date. The date of the biography puts a "timestamp" on the data, which ranges from 1987 to $2002^{28}$. In the 319 cases where the date is known, 35 percent (111) occurred between 1992-1995 and 57 percent (183) occurred between 2000-2002.

27 Hamas's website http://www.palestine-info.net/arabic/hamas/shuhda/shuhda.htm later replaced with http://www.palestine-info.info/arabic/hamas/shuhda/shuhda.htm

The Hamas's military wing (Iz Al Din Al Qassam) online journal describes its "Martyrs" on http://www.qassam.org/shohadaa/shohadaa_1990/photo_1990/1990.htm

to http://www.qassam.org/shohadaa/shohadaa_2002/photo_2002/2002.htm for the respective years and on Hamas's Al Qassam shuhada memorial association http://www.sabiroon.org/.

Palestinian Islamic Jihad's online journal http://www.qudsway.com/, their website ("Jihad Islami”) http://www.jihadonline.org/ and http://www.shuhadaa.com/

Finally, additional limited data can be found on the Palestinian authority official websites http://www.pnic.gov.ps/arabic/quds/quds_e_martyrs.html and http://www.pnic.gov.ps/arabic/quds/martyrs/martyrs.html

(Note that most Martyrs in the PA websites are not considered terrorists by my definition so that those sites were used only to complement data on already-identified terrorists).

${ }^{28}$ The first biography is dated October 6, 1987 and the latest biography I have included in the data set is dated May 6, 2002 (I have continued to collect the biographies published since, but more recent biographies await translation). 
Of the 171 observations from which it can be determined whether or not the death was the result of a planned attack, approximately 89 percent (152) were planned attacks and approximately 11 percent (19) were not planned attacks. Out of the planned attacks, 66 (39 percent) were suicide attacks - 43 by Hamas members, 22 by PIJ members, and one by a member of both organizations. Cases where the attack was not planned include attacks initiated by the Israeli Defense Forces (IDF) and attacks carried out during or after resisting arrest. In the cases where it was clear that the "Shahid's" death was the result of an IDF extra-judicial execution (targeted assassination), it was necessary to check available resources to determine whether the "Shahid" had committed previous terror attacks or been arrested, in order to establish his presence, or lack thereof, on the list of terrorists. In addition, 95 of the observations included information about the existence or non-existence of a will; approximately 93 percent (88) included a will showing that the "Shahid" knew his death was near.

Out of the 335 biographies, 114 gave specific details on whether or not the individual participated in one or more previous attacks. Of those 114, 96 percent (109) participated in previous terror attacks, leaving only five biographies indicating clearly that the "Shahid" had no prior terrorist activity. Also, out of the 173 cases in which it was known whether or not the individual had been arrested for participating in terrorist activity, 91 percent (158) had been arrested previously for participating in terrorist activity.

From 284 observations that give a clear indication of rank in the organization, 68 percent (193) were foot soldiers and 32 percent (91) were leaders. The leader category includes cell commanders in charge of cells of 3-6 foot soldiers. All available biographies are of males, of which 32 percent (106) were married, 39 percent (132) were single, and there was no information for the remaining 29 percent (97). The biographies describe men covering a very wide spectrum of professions, from doctors to teachers to unskilled workers, as well as full-time employees of terror organizations, i.e., Hamas and PIJ.

54 percent (168) of the terrorists lived in urban localities and 23 percent (73) lived in refugee camps. For the 306 cases in which the place of birth is known, 96 percent (293) were born in the West Bank or Gaza Strip. Out of the 284 for which both place and year of birth are known, 25 percent (71) were born while the territories were under Jordanian 
rule (West Bank) or Egyptian Rule (Gaza Strip), and 75 percent (213) were born after the territories were under Israeli rule.

In 215 biographies the terrorist's religion was either clearly indicated or could be deduced indirectly from the information, and in all cases, the individual was Muslim. The religion was not indicated in the rest of the biographies, but it is reasonable to assume that the others were Muslims as well, given the nature of the organizations to which they belonged (since both Hamas and PIJ are religious Muslim organizations and their militant activity is defined as Jihad-a Muslim, religious war). In addition, there were 165 biographies with descriptions of some kind of religious studies.

Inferring poverty status presented more of a challenge. Although some biographies clearly implied an individual's poverty status in statements such as "he lived in poverty" or "he was a wealthy man," this was not the case for all observations. When possible, poverty status was inferred from available information on the individual's occupation, foreign travel history (e.g., traveled abroad), car ownership, computer availability, etc. For example, in one biography it was mentioned that the individual dropped out of college due to financial burdens, on another biography it was mentioned that the individual owned a new car which he used for weapon's smuggling. In such cases, I classified the former as poor while not the later. In other cases I relied on family background descriptions, such as parents' occupations, to infer poverty status. For example, one biography described the financial dependency of the individual's family on charity networks since his father was sick and couldn't afford paying the medical bills, on another biography it was mentioned that the individual's family owned a successful luggage factory and that the father is one of the wealthiest businessmen in the area. Once again, I classified the former as poor while not the later. Poverty status information could be inferred for approximately 69 percent (230) of all cases.

One of the advantages in using the method of data collection from reports about "Shahids" [deceased martyrs] derives from the fact that reporting about the "Shahid" is a highly divine obligation, and according to Islam it is considered a sin if one does not hail 
a "Shahid" 29 As a result, it is probably safe to assume that most of the militants from the terrorist organizations that died were reported in one way or another. Therefore, by collecting the data from the organizations' own publications and newspapers, some information should exist for each and every "Shahid" that belonged to the organizations.

Obtaining data on the general population in the West Bank (Judea and Samaria) and Gaza Strip for the relevant period proved to be difficult as well. The latest reliable and organized data available was for 1993 from the "Labor Force Surveys in Judea, Samaria and Gaza" (ISDC 1995), which includes all residents of Judea, Samaria and Gaza living in households, not including Israeli residents living in these areas 31 The sampling methods and definitions used in this Survey are similar to those used in the Israeli Labor Force Surveys.

This survey of households in the West Bank and Gaza Strip has been continually conducted by the Central Bureau of Statistics from August 1968 to September 1995, when each household was investigated four times over six quarters. The survey consisted of two investigations during two consecutive quarters and, after a break of two quarters, two additional investigations. The household questionnaire contains details of household composition and dwelling. The personal questionnaire (answered by persons aged 15 and over) includes basic demographic as well as labor force characteristics and job location (in Israel or in the territories and wages of workers).

Due to the events of the $1^{\text {st }}$ Intifada in the West Bank and Gaza Strip area from the end of 1987 through 1991, enumeration suffered from difficulties of coverage as well as from fewer quality responses. Also, since the April-June 1994 Survey, the data does not contain population figures from the autonomous areas of Gaza and Jericho (i.e. a significant part of the area relevant for a control group has been under PNA control since 1994). Due to the current situation in the PNA areas and administration, I could not attain more recently updated data. These facts combined with the facts that more than a third of

\footnotetext{
${ }^{29}$ Ergun M. Caner, professor of theology and church history at Criswell College in Dallas and co-author of "Unveiling Islam" with his brother Emir, used a similar argument when asked if he was sure that Osama Bin Laden was still alive after the US bombings in Afghanistan.

${ }^{30}$ Although biographies probably exist for every "Shahid", some did not contain any relevant data that could be used for statistical analysis.

${ }^{31}$ This data was used by Joshua Angrist (1995). "The economic returns to schooling in the West Bank and Gaza Strip”, American Economic Review, Vol. 85, 4, Dec. 1995.
} 
the Hamas and PIJ biographies with known publication dates are from the 1992-95 period and 96 percent (293) of the 306 individuals for whom place of residence was known resided in the West Bank or Gaza Strip made me consider the 1993 survey population of similar age, sex and religion to be the most appropriate control group available. Another advantage to using the "Labor Force Surveys in Judea, Samaria and Gaza" is the size of the 1993 survey sample (99,193 observations) and its quality.

Because the sample of terrorists contained only Muslim males between 15 and 56 years old, I have restricted the survey sample to the 41,762 Muslim males between the ages of 15 and 56 as well.

In the last decade, the income and education levels of the inhabitants of the West Bank and Gaza Strip deteriorated due to political and security reasons caused by the ongoing conflict in the region. Therefore, the use of control group data from 1993 instead of more recent data may, if anything, under-represent the poor and less educated in the population.

With respect to educational attainment it was not a priori evident that it did not rise in the last few years, something that, if true, would make the use of control group data from 1993 inappropriate. A comparison was then performed between the educational distribution of the Palestinian population in the relevant ages obtained from the 1993 survey sample and the distribution obtained from a survey collected by the Palestinian Center for Policy and Survey Research (PCPSR) from December 19 to 24, $2001 .{ }^{32}$ From the comparison displayed in appendix B, it is clear that, if anything, educational attainment was lower in 2001 compared to 1993. Therefore, once again, the use of control group data from 1993 instead of more recent data may, if anything, underrepresent the less educated in the population.

The following potential problems with the terrorist biographical data and the survey data are worth emphasizing:

- There is no indication in the "Labor Force Surveys in Judea, Samaria and Gaza" whether or not an individual is also engaged in Hamas or PIJ terrorist activities.

\footnotetext{
${ }^{32}$ The questionnaire and aggregate results are available from: http://www.pcpsr.org/survey/polls/2001/p3a.html The breakdown of this data by educational level was provided by Alan B. Krueger, Bendheim Professor of Economics and Public Affairs at Princeton University.
} 
However, I estimate the Hamas and PIJ active militants to represent less than 1 in 1,000 people and suicide bombers to represent less than 1 in 100,000 people in the relevant gender, age, and religion group of the population. I ignore the fact that, in principle, some individuals of the survey sample may have belonged to those terrorist groups as well.

- Most of the deceased terrorists died during a planned terrorist attack on their part; however, some died due to Israeli targeted assassinations. Since targeted terrorists are presumably of higher rank, and thus higher income and/or education, the results might suffer from a bias that would be introduced by the overestimation of relatively better off terrorists. In order to evaluate this potential bias, all tests were repeated using only the 157 observations for which I knew from the biography that the attack was premeditated. The results remained identical in signs and statistically significant.

- Because of the division of labor within any organization, different activities are assigned according to one's rank. Assuming that lower ranking terrorists are assigned riskier tasks, it is probable that the share of low ranked soldiers within the set of deceased is larger than their share in the organization. If so, my sample would underrepresent the number of highly educated terrorists from middle or upper income families.

- Another consideration might be given to a potential reporting bias. One might suspect that since these biographies are intended to hail the deceased they would refrain from publishing facts that might be considered unflattering or humiliating. In fact, the suspicions increase when one reads the many lengthy descriptions of the deceased's devotion to the religion and to the cause, which never mention the possible doubts in the goals or the means that they employed. Also, the clearly exaggerated glorifications indicating the bravery of the deceased adds to the suspicion of reporting objectivity bias. It is not clear, however, if descriptions of one's wealth would be exaggerated in a society where being poor is associated with humbleness. In fact, in biographies in which poverty is mentioned, it is clearly emphasized with pride. Some biographies, however, indicated wealth with pride, suggesting that it was associated with a position of respect for the deceased and his family. If anything, it seems that extremities on both sides might be over represented, since average wealth or income 
might not add to the glorification and commemoration process. To overcome this problem, one would ideally want to have another, orthogonal source of reporting for comparison. To the best of my knowledge, no additional sources exist. In the only case where an individual's biography was reported by both the Hamas and the PIJ, the articles tended to be in agreement.

- An additional problem arises from the fact that variables of interest (i.e. schooling and poverty) for some individuals were inferred on the basis of existing information. For example, I used the type of last school attended or the highest degree achieved in order to infer the number of years of schooling. Thus, the data may not be perfectly comparable.

- Potentially the most significant problem is the fact that in most cases poverty status of terrorists was inferred from variables indicating one's wealth. However, the population survey data did not give any information on the individual's (or the family's) accumulated wealth. Ideally, I would use an identical variable, from both the population survey data and for the 'Shahids' biographical data, indicating if a minimum substance level is met or not. In the absence of such a variable, monthly wage was used to determine poverty status in the population survey. On the one hand, the measures are hardly comparable, but on the other hand, we also know from theoretical works (Danforth, 1979) as well as empirical evidence (Bloemen and Stancanelli, 2001) that higher levels of wealth result in higher reservation wages, thus higher wages for the ones employed. Moreover, the criteria for being considered poor among the population survey has been increased in an attempt to 'bend the curve backward,' whereas I have classified a 'Shahid' above poverty only when the biography indicated possessions or a standard of living that would not be possible when destitute. So, only individuals with extremely low wages ${ }^{33}$ were considered poor in the survey population. The cutoff point was set at the point that someone earning such a wage could not possibly afford to maintain the assets possessed by the above-poverty terrorists. For example, owning a car would not be possible due to maintenance costs alone, travels abroad would be out of reach, etc. Additional

\footnotetext{
${ }^{33}$ In order to be categorized as poor, one had to earn less than $40 \%$ of the Israeli minimum wage, which is approximately equal to $18 \%$ of the Israeli average wage.
} 
exogenous information, such as the very limited fraction of the population that has access to a car (approx. 20 percent) or a computer (approximately 4 percent) ${ }^{34}$, would suggest that, when comparing to the terrorists' data, the share of the above-poverty in the general population has been overestimated. In fact, the level of poverty I obtained from the population survey data (31 percent) is significantly lower than other source estimate $\frac{35}{3}$.

\section{Time Series Terrorist Attacks and Economic Indicators Data}

For time series analysis purposes, an additional data set was constructed containing daily information on each and every fata ${ }^{36}$ terrorist attack against noncombatants 3 that occurred on Israeli soil ${ }^{88}$ from 1949 to January 31,2003 . Every attack is described by date, method of operation, location, terrorist organizations claiming responsibility, and additional data about the victims, such as age, gender, and place of residence. The procedure in which the data was collected was as follows:

First, data was gathered from the Israeli Foreign Ministry, which publicly provides a list containing major terrorist attacks for which the description is fairly detailed, although it lacks information in some cases 39 . Since the information provided by the Israeli Foreign Ministry only covers certain time periods, it was necessary to search for data from other sources. I chose the information provided by the National Insurance Institute of Israe ${ }^{40}$ (NIII) for the time periods that data from the Israeli Foreign Ministry was unavailable. The main reason I chose the NIII to create a continuous data set is because it is regulated by the government, and is therefore very reliable. In fact, the NIII is

\footnotetext{
${ }^{34}$ Palestinian Central Bureau of Statistics - Table 25 : Percentage of Palestinian Households By Availability of Some Durable Goods (1997).

${ }^{35}$ A report from January 2003 produced by William Bell, a Christian Aid policy officer for Palestine and Israel find that "Almost three-quarters of Palestinians now live on less than US\$2 a day - below the official UN poverty line." http://www.christianaid.org.uk/indepth/0301isra/losing.htm

${ }^{36}$ Due to the collection procedure constraints, only attacks in which someone besides the terrorist died were included.

${ }^{37}$ The term noncombatant is interpreted to include, in addition to civilians, military personnel who at the time of the incident are unarmed and/or not on duty.

${ }^{38}$ This includes occupied territories when under Israeli control.

${ }^{39} \mathrm{http}: / /$ www.israel-mfa.gov.il/mfa/home.asp

${ }^{40}$ The National Insurance Institute of Israel is Israel's counterpart to the U.S. Social Security Administration. http://www.btl.gov.il/
} 
obligated by law ${ }^{41}$ to track every registered death and compensate relatives in cases of deaths caused by terrorist attacks $\frac{42}{2}$. Despite the lack of inaccuracies and perfect continuity of a data set comprised solely of data from the NIII, compiling such a data set would require extensive further research (the research techniques are described below for the cases included in this data set).

The information provided by the NIII concerns deceased individuals on a case-bycase basis 44 . Each death appeared on a different file and, when all necessary information was not included for a particular case, required additional newspaper archival research in order to distinguish the case as a victim of a terrorist attack (versus other acts of hostility) and to be included in the data set. Additional research in Israeli newspapers such as Ha'aretz and Ma'ariv, which obviously had to be translated, was also necessary to gather relevant data on the attacks, such as location, type of attack, organizations claiming responsibility, etc. (this information was not provided by the NIII, since they deal with the individual victims and not the perpetrators). Another source of data came from the Israeli Defense Forces (IDF). The IDF keeps most of its data confidential, so access to the more detailed, classified data proved impossible. Therefore, only the publicly provided summarized data was used for cross-reference purposes. To the best of my knowledge, this is the most accurate, comprehensive, unclassified dataset available

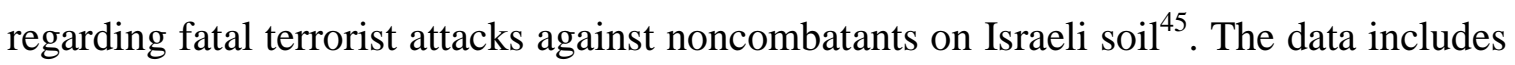
information on 1,857 fatalities from 883 attacks 46 .

Data from the ICBS (Israeli Central Bureau of Statistics), the PCBS (Palestinian Central Bureau of Statistics), and the CIA World Factbook was used to obtain the size of the Israeli and Palestinian populations, the total area controlled by Israel at the time of the

\footnotetext{
${ }^{41}$ The author's free translation is: The law of benefits to victims from hostilities, 1970. חוק התגמולים לנפגעי איבה תש"ל 1970

${ }^{42}$ The law specifies that any Israeli citizen or resident, or a person who entered Israel legally, who was injured by an act of hostility, is eligible for benefits. Monthly Dependent's Benefits are paid to the widows or parents of a person who passed away due to a hostile action. Hostile action injury/death - an injury/death due to an act of hostility by enemy forces or under circumstances in which there was reasonable fear of hostile actions, as well as injury/death caused by a weapon that was intended for hostile actions - all conditional upon approval by the authority appointed by the Ministry of Defense that this is a hostile action.

${ }^{43}$ I have compared the data collected from the Israeli Foreign Ministry with several randomly chosen cases collected from the NIII and found no case of discrepancy.

${ }^{44} \mathrm{http} / / / \mathrm{www}$.laad.btl.gov.il/

${ }^{45}$ A summary of attacks and deaths appears in Appendix A.

${ }^{46}$ This includes 515 deaths from 75 suicide attacks.
} 
attacks, and additional economic variables regarding the Palestinian population at time of attacks, such as GDP and average wage.

As with the biographical data, potential problems arise with the time series terrorist attacks data and the economic variables data that are worth emphasizing.

- The time series terrorist attack data includes only attacks in which someone besides the terrorist died, so that foiled attacks as well as "unsuccessful" attacks in terms of producing casualties, as well as terrorist attacks outside Israel ${ }^{47}$ are not counted. Since we are interested in the variables inducing participation in terrorist activities and not necessarily "successful" or local terrorist activities, we might be omitting relevant terrorist events. In addition, fatal attacks for which the perpetrator remained unknown are counted. Such attacks should not be included if not committed by Palestinians or if committed by Palestinians who do not live in the Palestinian territories, and thus are not directly affected by the economics of the region.

- The economic indicator variables data was collected from different sources since no one source could provide continuous data for the region. The differences between the sources in their methodology, definitions and the actual geographic area they covered might be significant and could potentially reduce the validity of any year-to-year comparison. I have tried to control for this problem by introducing dummy variables for the different sources.

Despite the limitations of the different data sets, the sample of terrorists does provide information on the characteristics of individuals engaged in Hamas and PIJ terrorist activities (and suicide bombers in particular), while the time series analysis can help answer the broader questions about the links between economic conditions and terrorism.

\footnotetext{
${ }^{47}$ Including occupied territories.
} 


\section{Estimation Strategies:}

As previously discussed, one goal of this paper is to incorporate covariates and estimate the correlates of participation in Palestinian terrorist (Hamas and Palestinian Islamic Jihad) activities in general as well as the correlates of becoming a Hamas or PIJ suicide bomber, in particular. The data used was extracted from terrorists' biographies as well as the "Labor Force Surveys in Judea, Samaria and Gaza" from which I have drawn a relevant comparison group ${ }^{48}$.

Preliminary tabulations of demographic characteristics broken down by the groups of interest (i.e., terrorists or suicide bombers versus the general population) suggest that there are differences between the general population and the terrorist sample. A Chisquare test performed on each of the relevant characteristics refers to a test of the null hypothesis that the characteristic is independent of terrorist status.

In order to see if the tabulation results hold statistically when introducing control characteristics I used a logistic probability model. Specifically, I model the effect of suspected variables of influence (i.e. schooling and poverty status) on the outcome $\left(y_{i}\right)$ as: $y_{i}=x_{i} \beta_{1}+$ schooling $_{i} \beta_{2}+$ poverty $_{i} \beta_{3}+e_{i}$ where $y_{i}$ is a discrete variable that equals 1 if the outcome is positive (e.g., if the individual participated in Hamas or PIJ terrorist activities), and equals 0 otherwise. $y_{i}$ might be a function of several other observed characteristics, $x_{i}$, which include age, marital status, place of residence, employment status, etc., so those variables were included when found fit. The coefficients $\beta_{2}$ and $\beta_{3}$ would then be the logistic estimates of schooling and poverty status, respectively, on the dependent variable. From these coefficients, the slope (marginal effect) can be easily calculated. However, this setup presents a classic problem of choice-based sampling because the terrorists were selected for inclusion in the sample on the basis that the dependent variable of the logistic equation equals one. Consequently, the sample does not constitute a random sample and the estimates will generally be inconsistent (Manski and Lerner, 1977). Weighting the data by the ratio of the estimated relative frequencies of the

\footnotetext{
${ }^{48}$ See section $\mathrm{V}$ for details about the data and the collection procedure.
} 
subjected groups in the population to their relative frequencies in the sample should yield consistent estimates

For the purpose of analyzing the effect of economic condition on the number of terrorist attacks, a panel of economic indicators and time series data on terrorist attacks for the matching periods ${ }^{60}$ is implemented. Because the number of attacks is a count variable, a linear regression model is inappropriate. Since I could not assume a priori equality of the conditional mean and variance functions, I estimated a negative binomial regression model.

Specifically, I modeled the bivariate relationships as: $\log \left(y_{t}\right)=\beta x_{t}+e_{t}$, where $y_{t}$ is the number of terrorist attacks in year $t$, and $x_{t}$ is the economic indicator (e.g., GDP growth, the $\log$ of the average wage, etc.) for year $t$. In cases where the economic indicator variables were taken from two different sources (e.g., the ICBS and the PCBS), a dummy variable was used to control for the possibility of incongruous values that could result from differences in collection methods between the sources. The relationship then becomes $\log \left(y_{t}\right)=\beta_{1} x_{t}+\beta_{2} d_{t}+e_{t}$, where $d_{t}$ is the dummy variable for year $t$. Similarly, if the data was taken from three different sources, I included two dummies, one for every additional source. I also tested for the inclusion of a time trend, and repeated all estimations when controlling for population changes (i.e., including the log of population size on the right-hand side).

In the case of suicide attacks, any time series analysis would have been much less reliable due to the relatively short period at hand $\frac{51}{1}$, but I was able to double the number of observations by splitting the data into two main regions (i.e., Gaza and the West Bank). This was feasible because for most suicide attacks $\frac{52}{2}$ I was able to identify the

\footnotetext{
${ }^{49}$ Krueger and Maleckova (2002) encountered the exact same problem; I am following their suggested methodological technique to create consistent estimates.

${ }^{50}$ See section $\mathrm{V}$ for details about the data and the collection procedure. The length of the period analyzed in each case was set by the period for which the economic variables were to be found.

${ }^{51}$ The first suicide bombing attack in Israel is usually attributed to Sahar Tamam Nabulsi, who on April 16, 1993 used his truck as a guided bomb. This event, however, is not accounted for in my time series data since no Israeli citizen died in the incident. Depending on the exact definition of fatal suicide attack, the number of observations (years) could range from 9 (1994-2002) to 14 (1989-2002). This does not account for one event on December 11, 1974, which cannot conclusively be identified as a suicide attack.

${ }^{52}$ As of January 2003, for the 75 fatal suicide attacks since 1989 (68 since April 1994), the attack originated from the West Bank in 47 cases (45 cases since 1994) and from Gaza in 15 cases (10 since 1994). In 2
} 
place from which the terrorist originated (i.e., his place of residence). The identification was done by matching the dates of attacks from the time series data set with the dates of deaths from the biographies data set. ${ }^{[-3}$ I then used the variability in the economic performance and the number of suicide attacks originating from the two regions to model the relationship as follows: $\log \left(y_{r, t}\right)=\beta x_{r, t}+e_{r, t}$, where $y_{r, t}$ is the number of suicide attacks in which the terrorist's place of residence is $r$ at year $t$, and $x_{r, t}$ is the value of the economic variable for region $r$ at year $t$.

other cases the suicide attacker was known to be from another region, and for the other 11 cases the origin of the attacker remained unknown.

${ }^{53}$ Additional information was compared to validate the match. 


\title{
VII. Sample Descriptive Statistics and Estimation Results:
}

\author{
Correlates of participation in Palestinian terrorist (Hamas and Palestinian Islamic Jihad) \\ activities:
}

\section{Sample Descriptive Statistics}

Table 1.1 reports the means of selected demographic variables for Palestinian (Hamas and PIJ) terrorists and the Palestinian population of similar age, sex and religion, as were tabulated using the data set culled from the terrorists' biographies as well as the "Labor Force Surveys in Judea, Samaria and Gaza". The right-hand column displays the results of a Chi-square test run on each of the relevant characteristics and refers to a test of the null hypothesis that the characteristic is independent of terrorist status.

An interesting finding of this data is that 31 percent of the Palestinians, compared to

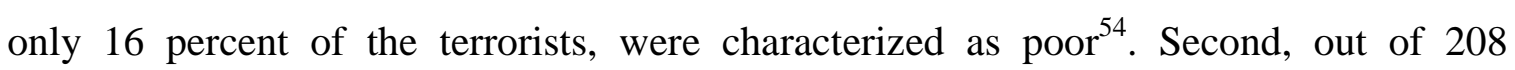
observations where information about the terrorist's education was available, approximately 96 percent (200) have at least a high school education and approximately 65 percent (135) have some kind of higher education, compared to 51 percent and 15 percent, respectively, in the Palestinian population of same age, sex and religion.

Third, age of the terrorists was either directly indicated in the biographies as the age of death (for those who died), the age at expelling time (for those that were expelled to Lebanon), or it was computed from the date of publication and the date of birth, when available. Age at or just prior to the time of publication was known or possible to compute for 296 of the terrorist biographies. The Palestinian population contains a larger share of its individuals at prime time earning ages (58 percent between 25 and 54 years of age) when compared to the terrorists (only 51 percent in the same age range). Compared to the general population, terrorists tend to be younger: where only 72 percent of the general population is below the age of 34,91 percent of terrorists fall into this group.

Fourth, terrorists tended to be from urban areas (54 percent of the 311 observations where this information was available), whereas only 34 percent of the Palestinian

\footnotetext{
${ }^{54}$ See section $\mathrm{V}$ for the way that individual's economic status was inferred in each of the populations and the potential problems introduced by it.

${ }^{55}$ Given the age distribution differences, the finding described previously (of differences in poverty and education) become even more striking.
} 
population was living in urban areas. In particular, 47 percent of the terrorists lived in Gaza, compared to only 22 percent of the comparable population.

Fifth, only 45 percent of the terrorists were married, compared to an average of 59 percent in the population of individuals with similar age, sex and religion 56 . Finally, out of 142 observations where information about labor force status of the terrorists was known, 94 percent held some kind of employment, whereas only 69 percent of the Palestinian population was employed.

Table 1.2 reports the means when the sample is restricted to include only individuals between 18 and 41 years of age (slightly more than 94 percent of the Hamas and PIJ sample fall under this age range), and Table 1.3 is restricted further not to include the 50 PIJ leaders deported on December 17, 1992. The means presented in Tables 1.2 and 1.3 do not differ significantly from the ones obtained using the more inclusive sample reported on Table 1.1. Table 2.1 shows similar, though weaker differences, in the findings when characteristics of only suicide bombers are compared to the characteristics of the Palestinian population of same age, sex and religion. Table 2.2 displays the results when the sample is restricted to include only individuals between 17 and 28 years of age (slightly more than 90 percent of the suicide bombers sample fall under this age range). None of the 50 PIJ leaders deported on December 17, 1992 became suicide bombers, so that their exclusion was irrelevant. Tables 3.1 - 4.3 compare the characteristics of Hamas terrorists and the PIJ terrorists separately with the characteristics of the Palestinian population of the same age, sex and religion. The findings in general are similar to those of Table $1.1 \frac{67}{\text {. }}$.

\section{Estimation Results}

Table 5.1 provides logistic estimates using the pooled sample of terrorists (Hamas and PIJ) and the "Labor Force Surveys in Judea, Samaria and Gaza" of 1993. The dependent variable equals one if the individual is a Hamas or PIJ terrorist, and zero

\footnotetext{
${ }^{56}$ One should remember, however, the different age distribution mentioned earlier.

${ }^{57}$ One exception is poverty in Table 4.3 (in which the PIJ sample is restricted to include only individuals between 17 and 28 years of age, and restricted further not to include the 50 PIJ leaders deported on December 17, 1992) where the means are such that a chi-sq test could not reject the null hypothesis that the poverty characteristic is independent of PIJ terrorist status.
} 


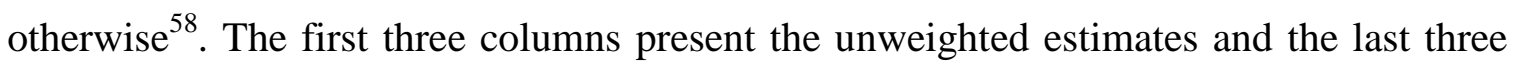
columns present the weighted, consistent estimates. All estimates are statistically significant, and suggest that poverty is inversely related, and education is positively related, with the likelihood that someone becomes a Hamas or PIJ terrorist. The results remain similar and identical with respect to sign and significance of the coefficients when the sample is restricted not to include the 50 PIJ leaders deported on December 17, 1992 (Table 5.2), and to include only individuals between 18 and 41 years of age (Table 5.3). Table 6.1 presents the logistic estimates of the same analysis with regard to Hamas and PIJ suicide bombers. The results are similar in terms of the directions of the effects and are all statistically significant, as well. Restricting the sample to include only individuals 17-28 years old did not alter the results (Table 6.2).

Introducing regional and marital status dummy variables into the equations improved the $\log$ likelihood fitness of the estimations, plus both dummies were statistically significant. An additional potentially valid control variable, the type of residence (refugee camp versus urban or rural localities), was insignificant once the regional dummy was included. Moreover, the inclusion of the type of residence dummy did not change any of the other results in terms of the signs or and significance of the coefficients.

\section{The effect of economic condition on the number of terrorist attacks:}

\section{Estimation Results of Time Series Analysis}

Table 7 provides the coefficients of the negative binomial regression of the number of terrorist attacks (as the dependent variable) and the annual logarithm of the average wage (as the independent variable of interest). At first, the annual average wage was positively correlated with the number of terrorist attacks, but the coefficient was insignificant. Introducing a dummy variable to control for the possible differences of measures in the levels of the average wage when collected from different sources caused the effect to remain positive and become statistically significant at the 15 percent significance level. These results are very sensitive to specification, as is apparent from columns 3, 4 and 5 .

\footnotetext{
${ }^{58}$ Refer to section VI for more details about the estimation strategy and the problem of choice-based sampling.
} 
Adding control variables brings back the positive correlation, but the coefficients remain insignificant.

The estimates from a repetition of the above exercise using growth in GDP per capita as the independent variable, instead of the annual logarithm of average wage can be found in Table 8. The results show that the number of terrorist attacks moved procyclically (i.e. higher GDP growth was associated with a higher level of attacks) and the positive association becomes significant when controlling for the possible differences of measures in the levels due to the different sources, for the changes in population, and for a possible time trend.

Table 9 contains the estimates of the analysis of suicide attacks when the economic variable of interest is the lagged growth in GDP per capita. The analysis of suicide attacks required additional sophistication due to the short period at hand. ${ }^{59}$ Since GDP data were available for the West Bank and Gaza separately, two regions that jointly account for 94 percent of the suicide attacks for which I could identify the perpetrator's residence of origin, the suicide attacks data was split according to the perpetrator's residence between the two regions and analyzed with respect to the economic variables of the corresponding region. Hence, I was able to double the number of observations using the variability in the economic performance of the regions. For 6 of the 41 relevant suicide attacks, the region from which the perpetrator originated could not be identified; and in the case of 2 other attacks the perpetrator originated from outside the West Bank and Gaza. The first analysis using current GDP per capita growth yielded insignificant results under all the specifications. However, considering the one year lagged effect, as presented in Table 9, yields significant results when controlling for the possible differences of measures in the levels due to the different sources and for a possible time trend. Allowing a different level and slope between the two regions causes the significance level to improve. In all cases the number of suicide attacks moved procyclically.

\footnotetext{
${ }^{59}$ The first fatal suicide attack accounted for in my time series data occurred on July 6, 1989. On a yearly basis until 2002 (inclusive), this would yield a maximum of 14 observations. However, reliable GDP data for 1993, the year in which the ICBS ceased surveying the Gaza strip and Jericho while the Palestinian authorities were not yet prepared to start their own orderly surveys and statistics, is missing. Moreover, data for 2002 was not yet available at time of writing this section.
} 
Since it is conceivable that an increase in GDP or lagged GDP per capita would have a different impact, when compared to a decrease of those variables, on the tendency to carry out terrorist attacks, a dummy variable was introduced to the previously described models. The dummy equaled one for an increase in GDP or lagged GDP per capita, and zero otherwise. When introduced by itself and when included in a product with the main variable of interest, the dummy ended up being insignificant. 


\section{Conclusions}

If there is a link between income level, education, and participation in terrorist activities, it is either very weak or in the opposite direction of what one intuitively might have expected. According to the findings of this paper, there is no reason to believe that increasing the years of schooling or raising the income level of individuals, without simultaneously modifying the educational content and monitoring (or at least limiting) the possible use of any additional income, will decrease the trend towards terror, the level of terror, or using means of terror.

The importance of the use of education to fight terror is not invalidated, in spite of these disappointing findings, which suggest that increasing years of school enrollment and attainment of higher degrees by itself does not reduce the probability of participation in terrorist activities, and possibly increases participation. On the societal level, the findings are weaker and subject to different interpretations. However, in my opinion, the relationships are the same in direction, although much more complex.

Policy makers, when trying to reduce terrorism via education or income, should focus not on the amount of education but on the content of education; changing the substance when needed in order to create positive stimulations towards democracy, moderation, appeasement and coexistence. Not all education is equal, and as Martin Luther King once said in another context, "education which stops with efficiency may prove the greatest menace to society. The most dangerous criminal may be the man gifted with reason but with no morals." 60 It is sometimes obvious how educational tools are used to breed terrorism. Examples of this can be seen by excerpts from the school books of the Official Palestinian Authority education system. To demonstrate this point I have chosen a few

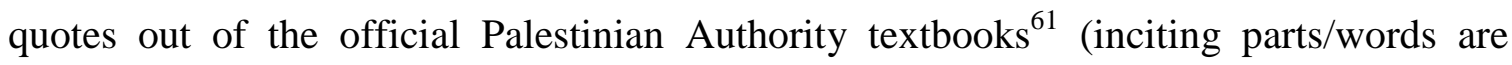
underlined):

\footnotetext{
${ }^{60}$ From Martin Luther King, Jr.'s speech to Morehouse College in 1948 on "The Purpose of Education." http://www.stanford.edu/group/King/publications/papers/vol1/470200-The_Purpose_of_Education.htm

${ }^{61}$ Material provided by "The center for monitoring the impact of peace": http://www.matckh.org/articles/pa-report.htm This organization is clearly not unbiased, but because I am using only the provided quotes from the original textbooks and do not rely on their interpretations, I have no reason to suspect inaccuracies.
} 
- "Know, my son, that Palestine is your country... that its pure soil is drenched with the blood of Martyrs ...Answer this: Why must we fight the Jews and drive them out of our land?" [Our Arabic Language for Fifth Grade \#542, p. 64-66]

- "Bayonets and Torches ... In your left hand you carried the Koran, And in your right an Arab sword ... Without blood not even one centimeter will be liberated Therefore, go forward crying: Allah is great." [Reader and Literary Texts for Eighth Grade \#578, p. 102]

- "Indeed, $\underline{\text { Satan }}$ has, in the eyes of many people, made their evil actions appear beautiful... Such a people are the Jews ..." [Islamic Education for Eighth Grade \#576, p. 95]

- "The clearest examples of racist belief and racial discrimination in the world are Nazism and Zionism." [Modern Arab History for Twelfth Grade, Part I \#648, p. 123]

- "My brothers! The oppressors [Israel] have overstepped the boundary. Therefore $\underline{\text { Jihad }}$ and sacrifice are a duty ... are we to let them steal its Arab nature ... Draw your sword ... let us gather for war with red blood and blazing fire ... Death shall call and the sword shall be crazed from much slaughter ... Oh Palestine, the youth will redeem your land..." [Reader and Literary Texts for Eighth Grade \#578, p. 120-122]

- "This religion will defeat all other religions and it will be disseminated, by Allah's will, through the Muslim Jihad fighters." [Islamic Education for Seventh Grade \#564, p. 125]

- "Martyred Jihad fighters are the most ... honored people, after the Prophets..." [Reader And Literary Texts for Tenth Grade \#607, p. 103]

- "Determine what is the subject, and what is the predicate, in the following sentences: The Jihad is a religious duty of every Muslim man and woman." [Our Arabic Language for Fifth Grade \#542, p. 167]

A quick overview of the content shown above is enough to let us suspect that in this case educational tools are used to breed terrorism among the Palestinian Youth. In addition, a major part of one's education is shaped or at least influenced at home. While 
school can only do so much to put contents into an already molded structure, this structure sometimes tends to be in support of terrorist activities and will find it easy to legitimate them.

The London-based Arabic-language daily Al-Sharq Al-Awsat published an interview with Umm Nidal, the mother of the "Shahid" [martyr] Muhammad Farhat $\frac{62}{6}$. When asked the question: "Did you have a role in the planting of this spirit [of becoming a suicide bomber] in Muhammad?" Umm Nidal answers: "Allah be praised, I am a Muslim and I believe in Jihad. Jihad is one of the elements of the faith and this is what encouraged me to sacrifice Muhammad in Jihad for the sake of Allah. My son was not destroyed, he is not dead; he is living a happier life than I. ... Because I love my son, I encouraged him to die a martyr's death for the sake of Allah... Jihad is a religious obligation incumbent upon us, and we must carry it out."

Another blatant example was when Yassar Arafat's (president of the Palestinian Authority) wife, Suha, said in an interview on April 12, 2002 with London's Arabiclanguage newspaper Al Majall that if she had a son, there would be "no greater honor" than for him to be a suicide bomber. Any educational system supportive of concepts like the one mentioned above would, in my opinion, only increase the probability of engaging in terrorist activities.

Similarly, economic prosperity will not eliminate terrorism by itself. If individuals have no restrictions on what they may or may not do with their increased income, they may use it to buy more and improved weapons and increase their terrorist activities. Perhaps surprisingly, even extreme expression of terrorist acts such as suicide attacks seems to follow improvements and not deteriorations in economic conditions. Policy makers, once again, should promote the creation of a strictly enforced judicial system in order to ensure that wealth is channeled to the right places.

\footnotetext{
${ }^{62}$ Al-Sharq Al-Awsat (London), June 5, 2002

English translation can be found at

http://memri.org/bin/articles.cgi?Page=archives \&Area=sd \&ID=SP39102
} 


\section{References}

Becker, Gary S. 1968. "Crime and Punishment: An Economic Approach." The Journal of Political Economy 76 (2): pp.169-217.

Berman, Eli. 2000. "Sect, Subsidy and Sacrifice: An Economist's View of UltraOrthodox Jews.” Quarterly Journal of Economics 115 (3): pp.905-953.

Berman, Eli. 2002. "Hamas, Taliban and the Jewish Underground: An Economist's View of Radical Religious Militias" Rice University, NBER October 2002.

Bloemen, Hans G. and Elena G. F. Stancanelli. 2001. "Individual Wealth, Reservation Wages, and Transitions into Employment." Journal of Labor Economics 19 (2): pp.400-439.

Danforth, John P. 1979. "On the Role of Consumption and Decreasing Absolute Risk Aversion in the Theory of Job Search." In Studies in the Economics of Search, ed. S.A. Lipmann and J.J. McCall: pp.109-31.North Holland: Amsterdam, 1979.

Ehrlich, Isaac. 1973. "Participation in Illegitimate Activities: A Theoretical and Empirical Investigation.” The Journal of Political Economy 81 (3): pp.521-565.

Federal Research Division. 1999. The Sociology and Psychology of Terrorism: Who Becomes a Terrorist and Why? Report authored by Rex. A. Hudson, Library of Congress, September 1999.

Green, Donald P., Jack Glaser, and A. Rich. 1998. "From lynching to gay-bashing: The elusive connection between economic conditions and hate crime." Journal of Personality and Social Psychology 75 (1): pp.82-92.

Hamermesh, Daniel S. and Neal M. Soss. 1974. "An Economic Theory of Suicide.” The Journal of Political Economy 82 (1): pp.83-98.

Hamm, Mark S. 1998. "Terrorism, Hate Crime, and Antigovernment Violence: A Review of the Research." In The Future of Terrorism: Violence in the New Millennium. London: SAGE: pp. 59-96.

Hassan, Nasra. 2001. “An Arsenal of Believers.” The New Yorker, November 19: pp.3641.

Iannaccone, Laurence R. 1998. "Introduction to the Economics of Religion." Journal of Economic Literature 36 (3): pp.1465-1495.

Israel Social Sciences Data Center-ISDC. 1995. Israeli Central Bureau of Statistics: Labor Force Survey in Judea, Samaria and Gaza 1981-1995. Issued by the ISDC and the Hebrew University of Jerusalem. 
Jefferson, Philip, and Frederic L. Pryor. 1999. "On the Geography of Hate." Economics Letters 65 (3): pp.389-395.

Lerner, Daniel 1958. The Passing of Traditional Society. The Free Press.

Kressel, Neil J. 1996. Mass Hate: The Global Rise of Genocide and Terror, New York: Plenum Press.

Krueger, Alan and Jitka Maleckova. 2002. " Education, poverty, political violence and terrorism: is there a casual connection?" Working Paper 9074, National Bureau of Economic Research, Cambridge, MA, July 2002.

Krueger, Alan and Jörn-Steffen Pischke. 1997. "A Statistical Analysis of Crime Against Foreigners in Unified Germany." Journal of Human Resources 32 (1): pp.1 82-209.

Manski, Charles and Steven Lerner. "The Estimation of Choice Probabilities from Choice Base Samples.” Econometrica 45 (8): pp. 1977-1988.

Russell, Charles and Bowman Miller. 1983. "Profile of a Terrorist." Reprinted in Perspectives on Terrorism, Wilmington, Delaware: Scholarly Resources Inc.: pp. 4560.

Viscusi, Kip W. 1986. "The Risks and Rewards of Criminal Activity: A Comprehensive Test of Criminal Deterrence.” Journal of Labor Economics 4 (3, Part 1): pp.317-340. 
Appendix A

Deaths (civilians) from terrorist attacks

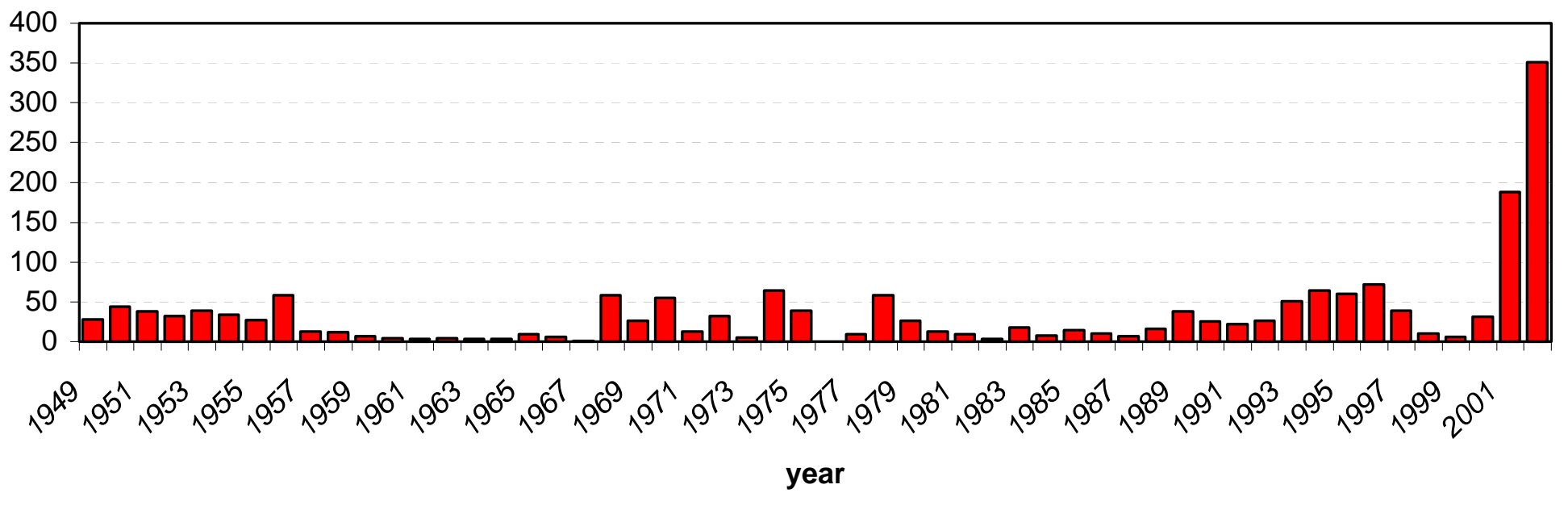

No. of fatal terrorist attacks

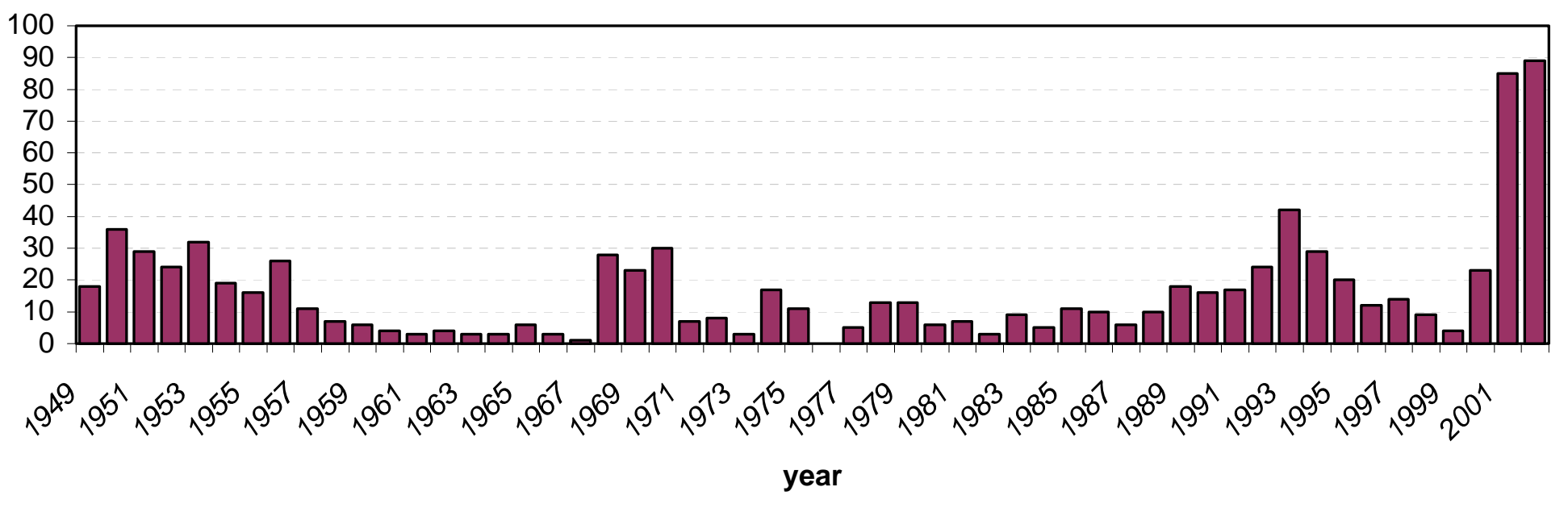



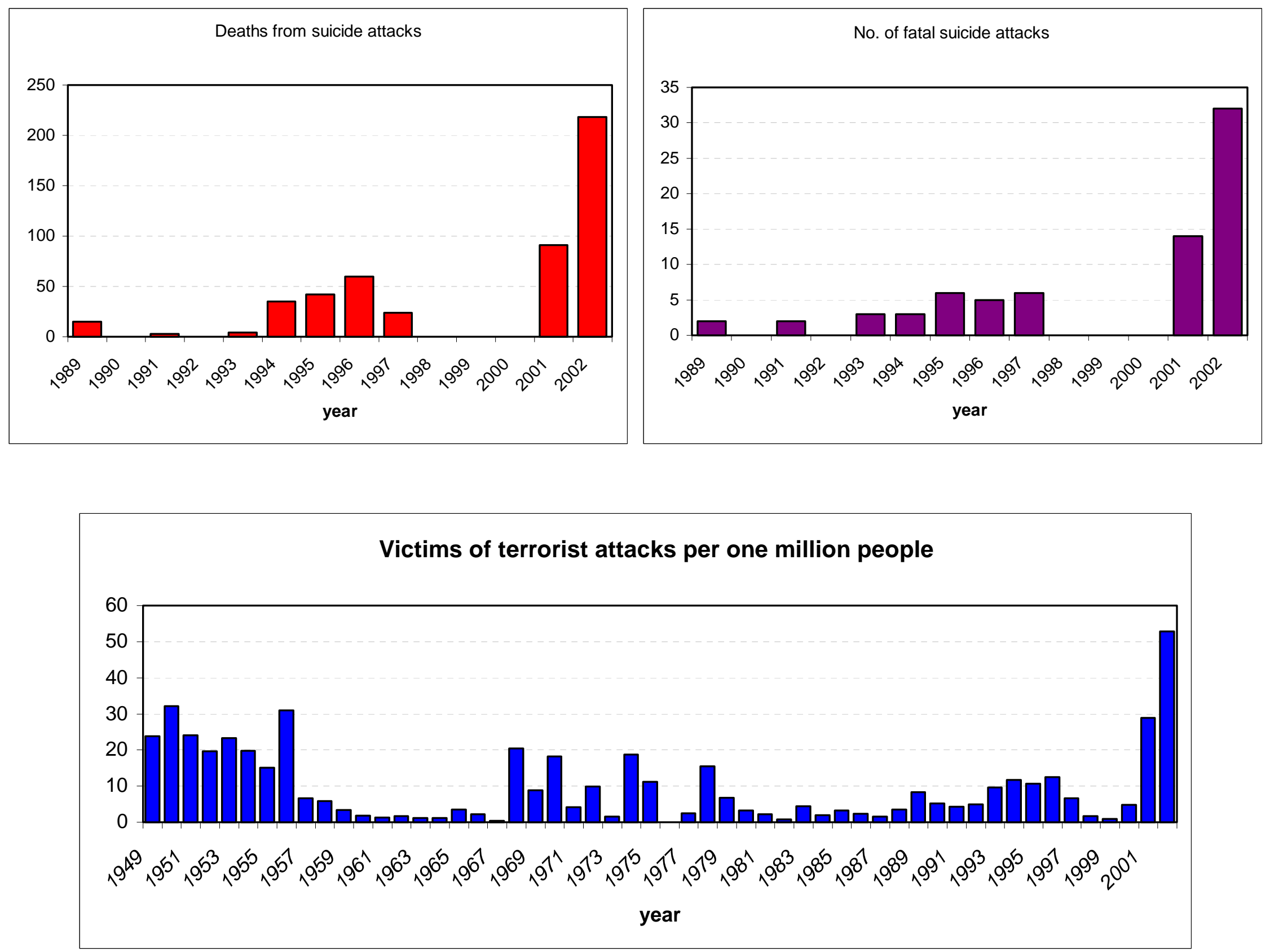

2 


\begin{tabular}{|c|c|c|c|c|}
\hline & $\begin{array}{c}\text { Deaths from terrorist } \\
\text { attacks since } 1949\end{array}$ & $\begin{array}{c}\text { Number of fatal } \\
\text { terrorist attacks since } \\
1949 \\
\end{array}$ & $\begin{array}{l}\text { Deaths from suicide } \\
\text { attacks since } 1949\end{array}$ & $\begin{array}{c}\text { Number of fatal suicid } \\
\text { attacks since } 1949 \\
\end{array}$ \\
\hline Daily Average & 0.094 & 0.045 & 0.026 & 0.004 \\
\hline Daily STD & 0.832 & 0.226 & 0.615 & 0.068 \\
\hline Daily Max & 33 & 3 & 29 & 3 \\
\hline Daily Min & 0 & 0 & 0 & 0 \\
\hline Weekly** Average & 0.658 & 0.313 & 0.182 & 0.027 \\
\hline Weekly** STD & 2.461 & 0.710 & 1.746 & 0.200 \\
\hline Weekly** Max & 41 & 8 & 32 & 3 \\
\hline Weekly** Min & 0 & 0 & 0 & 0 \\
\hline Monthly Average & 2.861 & 1.361 & 0.794 & 0.116 \\
\hline Monthly STD & 7.222 & 2.084 & 4.958 & 0.569 \\
\hline Monthly Max & 112 & 23 & 79 & 8 \\
\hline Monthly Min & 0 & 0 & 0 & 0 \\
\hline Yearly* Average & 33.907 & 16.259 & 9.111 & 1.352 \\
\hline Yearly* STD & 53.120 & 17.165 & 33.290 & 4.845 \\
\hline Yearly* Median & 24 & 11 & 0 & 0 \\
\hline Yearly* Mode & 3 & 3 & 0 & 0 \\
\hline Yearly* Max & 351 & 89 & 218 & 32 \\
\hline Yearly* Min & 0 & 0 & 0 & 0 \\
\hline \begin{tabular}{|c} 
TOTAL \\
\end{tabular} & 1857 & 883 & 515 & 75 \\
\hline
\end{tabular}




\section{Appendix B}

\begin{tabular}{|c|c|c|}
\hline \multicolumn{3}{|c|}{$\begin{array}{l}\text { Educational Distribution of Palestinian Population Age } \\
18 \text { or older in the West Bank and Gaza Strip as obtained } \\
\text { from the Palestinian Center for Policy \& Survey } \\
\text { Research, between 19-24 December } 2001 \text {. }\end{array}$} \\
\hline Other/DK & 12 & $1 \%$ \\
\hline Illiterate & 162 & $12 \%$ \\
\hline Elementary & 251 & $18 \%$ \\
\hline Preparatory & 347 & $26 \%$ \\
\hline Secondary & 368 & $27 \%$ \\
\hline College & 111 & $8 \%$ \\
\hline$B A$ & 101 & $7 \%$ \\
\hline$M A+$ & 5 & $0 \%$ \\
\hline No. of obs. & 1,357 & \\
\hline
\end{tabular}

\begin{tabular}{|c|c|c|}
\hline \multicolumn{3}{|c|}{$\begin{array}{l}\text { Educational Distribution of Palestinian Population Age } \\
\text { 15-56 Males and Muslims as obtained from the } 1993 \\
\text { "Labor Force Surveys in Judea, Samaria and Gaza" }\end{array}$} \\
\hline & & \\
\hline Other & 42 & $0 \%$ \\
\hline Primary & 8,509 & $21 \%$ \\
\hline Intermediate & 11,332 & $28 \%$ \\
\hline Secondary & 14,135 & $35 \%$ \\
\hline Vocational & 427 & $1 \%$ \\
\hline Post Secondary & 2,596 & $6 \%$ \\
\hline Academic institute & 3,237 & $8 \%$ \\
\hline No. of obs. & 40,278 & \\
\hline
\end{tabular}
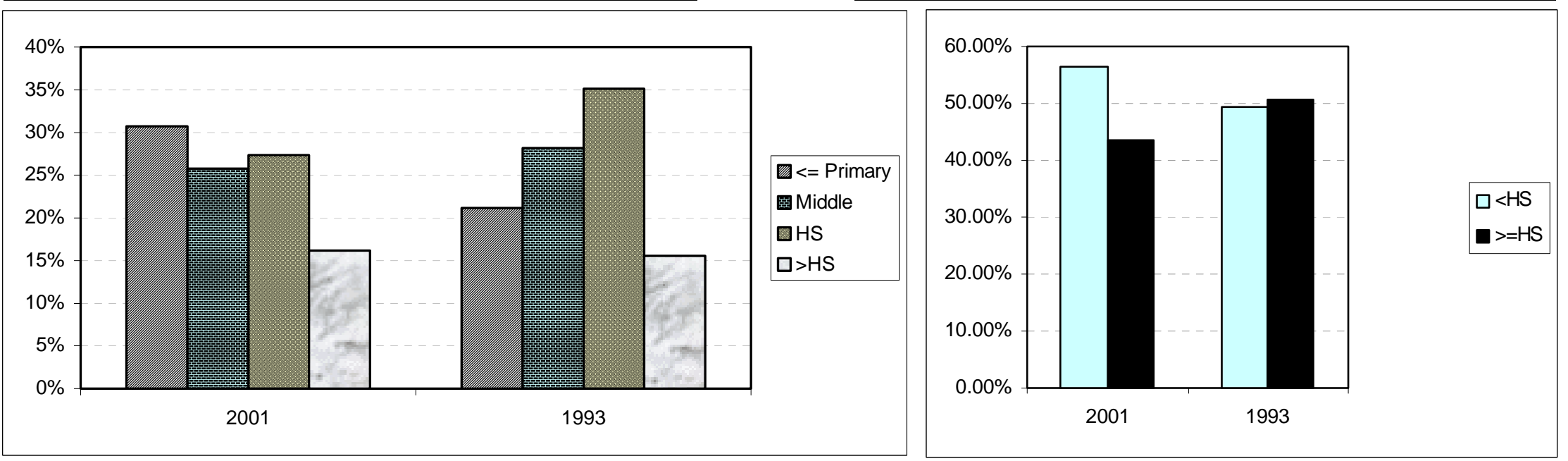


\section{Appendix C}

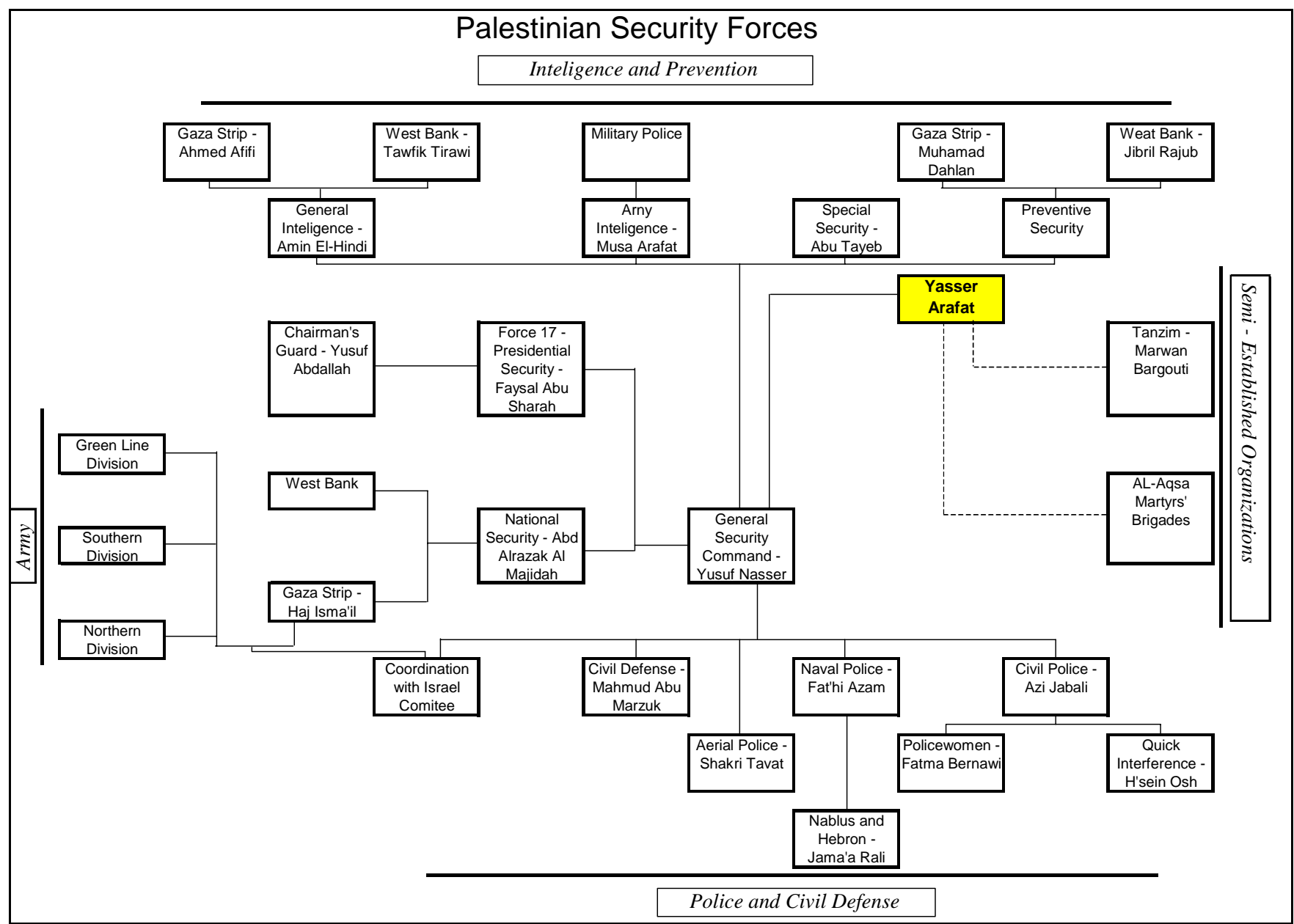

Information based on Ha' aretz internet special edition from June 8, 2001, 口and additional information collected since.

\footnotetext{
${ }^{1}$ The author's free translation of the title is: "The opposing army" by Avrahami Avner. הצבא שמנגד מאת אברהמי אבנר
} 


\section{Appendix D}

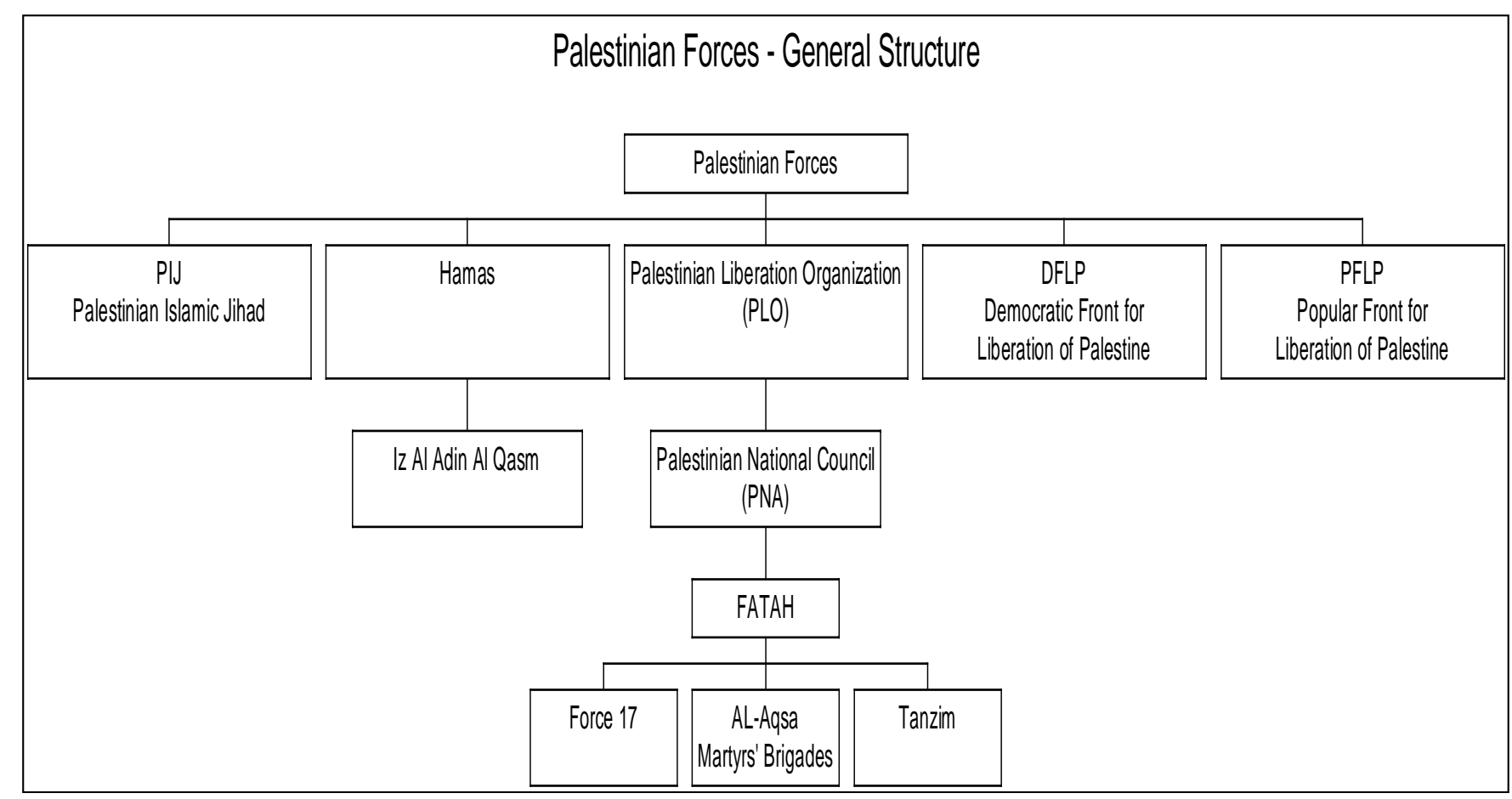




\section{$\underline{\text { Table } 1.1}$}

Characteristics of Palestinian (Hamas and PIJ) terrorists and Palestinian population of similar age, sex and religion.

\begin{tabular}{|c|c|c|c|c|c|}
\hline Characteristics & $\begin{array}{l}\text { Hamas } \\
\text { and } \\
\text { PIJ } \\
\text { terrorists }\end{array}$ & $\begin{array}{l}\text { No. of } \\
\text { obs. }\end{array}$ & $\begin{array}{c}\text { Palestinian } \\
\text { population } \\
\text { Age 15-56 } \\
\text { Males and } \\
\text { Muslims }\end{array}$ & $\begin{array}{l}\text { No. of } \\
\text { obs. }\end{array}$ & \\
\hline Poverty & & 230 & & 19590 & \\
\hline Poor & $16 \%$ & & $31 \%$ & & \\
\hline Average & $41 \%$ & & $48 \%$ & & \\
\hline Well & $33 \%$ & & $20 \%$ & & \\
\hline Very Well & $10 \%$ & & $0 \%$ & & \\
\hline & & & & & $\begin{array}{l}\text { p-value for chi-sq test }= \\
0.000\end{array}$ \\
\hline Age & & 296 & & 41762 & \\
\hline $15-17$ & $3 \%$ & & $12 \%$ & & \\
\hline $18-24$ & $45 \%$ & & $28 \%$ & & \\
\hline $25-34$ & $43 \%$ & & $32 \%$ & & \\
\hline $35-44$ & $7 \%$ & & $17 \%$ & & \\
\hline $45-54$ & $1 \%$ & & $9 \%$ & & \\
\hline $55-56$ & $0 \%$ & & $1 \%$ & & \\
\hline & & & & & $\begin{array}{l}\text { p-value for chi-sq test }= \\
0.000\end{array}$ \\
\hline Education & & 208 & & 40278 & \\
\hline Primary school & $4 \%$ & & $21 \%$ & & \\
\hline Intermediate & $0 \%$ & & $28 \%$ & & \\
\hline Secondary & $31 \%$ & & $35 \%$ & & \\
\hline Vocational & $8 \%$ & & $1 \%$ & & \\
\hline Post-secondary & $1 \%$ & & $6 \%$ & & \\
\hline $\begin{array}{l}\text { Academic } \\
\text { institute }\end{array}$ & $56 \%$ & & $8 \%$ & & \\
\hline Other & $0 \%$ & & $0 \%$ & & \\
\hline & & & & & $\begin{array}{l}\text { p-value for chi-sq test }= \\
0.000\end{array}$ \\
\hline $\begin{array}{l}\text { Residence } \\
\text { Type }\end{array}$ & & 311 & & 41762 & \\
\hline Urban & $54 \%$ & & $34 \%$ & & \\
\hline Rural & $23 \%$ & & $54 \%$ & & \\
\hline Refugee camps & $23 \%$ & & $13 \%$ & & \\
\hline & & & & & $\begin{array}{l}\text { p-value for chi-sq test }= \\
0.000\end{array}$ \\
\hline
\end{tabular}




\begin{tabular}{|c|c|c|c|c|c|}
\hline Characteristics & $\begin{array}{l}\text { Hamas } \\
\text { and } \\
\text { PIJ } \\
\text { terrorists }\end{array}$ & $\begin{array}{c}\text { No. of } \\
\text { obs. }\end{array}$ & $\begin{array}{c}\text { Palestinian } \\
\text { population } \\
\text { Age 15-56 } \\
\text { Males and } \\
\text { Muslims }\end{array}$ & $\begin{array}{c}\text { No. of } \\
\text { obs. }\end{array}$ & \\
\hline $\begin{array}{c}\text { School } \\
\text { Enrollment } \\
\text { Status } \\
\end{array}$ & & 231 & & 41762 & \\
\hline $\begin{array}{l}\text { Studied } \\
\text { previously }\end{array}$ & $71 \%$ & & $81 \%$ & & \\
\hline $\begin{array}{l}\text { Presently } \\
\text { studies }\end{array}$ & $29 \%$ & & $16 \%$ & & \\
\hline Never studied & $0 \%$ & & $3 \%$ & & \\
\hline & & & & & $\begin{array}{l}\text { p-value for chi-sq test = } \\
0.000\end{array}$ \\
\hline Marital Status & & 238 & & 41762 & \\
\hline Married & $45 \%$ & & $59 \%$ & & \\
\hline Divorced & $0 \%$ & & $0 \%$ & & \\
\hline Widowed & $0 \%$ & & $0 \%$ & & \\
\hline Single & $55 \%$ & & $41 \%$ & & \\
\hline & & & & & $\begin{array}{l}\text { p-value for chi-sq test }= \\
0.000\end{array}$ \\
\hline $\begin{array}{c}\text { Labor Force } \\
\text { Status }\end{array}$ & & 142 & & 41759 & \\
\hline $\begin{array}{l}\text { Full-time } \\
\text { employment }\end{array}$ & $90 \%$ & & $60 \%$ & & \\
\hline $\begin{array}{l}\text { Part-time } \\
\text { employment }\end{array}$ & $4 \%$ & & $6 \%$ & & \\
\hline $\begin{array}{l}\text { Absent from } \\
\text { work }\end{array}$ & $0 \%$ & & $3 \%$ & & \\
\hline Unemployed & $0 \%$ & & $6 \%$ & & \\
\hline $\begin{array}{l}\text { Not part of } \\
\text { labor force }\end{array}$ & $7 \%$ & & $25 \%$ & & \\
\hline & & & & & $\begin{array}{l}\text { p-value for chi-sq test }= \\
0.000\end{array}$ \\
\hline $\begin{array}{l}\text { District of } \\
\text { Residence }\end{array}$ & & 306 & & 41762 & \\
\hline Gaza & $47 \%$ & & $22 \%$ & & \\
\hline Judea Samaria & $49 \%$ & & $78 \%$ & & \\
\hline Northern & $1 \%$ & & $0 \%$ & & \\
\hline Central & $0 \%$ & & $0 \%$ & & \\
\hline Southern & $0 \%$ & & $0 \%$ & & \\
\hline Jerusalem & $3 \%$ & & $0 \%$ & & $\begin{array}{l}\text { p-value for chi-sq test }= \\
0.000\end{array}$ \\
\hline
\end{tabular}

Chi-square test refers to a test of the null hypothesis that the characteristic is independent of Hamas and PIJ status. 


\section{$\underline{\text { Table } 1.2}$}

Characteristics of Palestinian (Hamas and PIJ) terrorists and Palestinian population of similar age, sex and religion - sample restricted: only individuals between 18-41 years of age were included.

\begin{tabular}{|c|c|c|c|c|c|}
\hline Characteristics & $\begin{array}{l}\text { Hamas } \\
\text { and } \\
\text { PIJ } \\
\text { terrorists }\end{array}$ & $\begin{array}{l}\text { No. of } \\
\text { obs. }\end{array}$ & $\begin{array}{c}\text { Palestinian } \\
\text { population } \\
\text { Age 18-41 } \\
\text { Males and } \\
\text { Muslims }\end{array}$ & $\begin{array}{l}\text { No. of } \\
\text { obs. }\end{array}$ & \\
\hline Poverty & & 208 & & 16195 & \\
\hline Poor & $16 \%$ & & $32 \%$ & & \\
\hline Average & $41 \%$ & & $48 \%$ & & \\
\hline Well & $33 \%$ & & $20 \%$ & & \\
\hline \multirow[t]{2}{*}{ Very Well } & $10 \%$ & & $0 \%$ & & \\
\hline & & & & & $\begin{array}{l}\text { p-value for chi-sq test }= \\
0.000\end{array}$ \\
\hline Age & & 279 & & 30585 & \\
\hline $18-24$ & $48 \%$ & & $39 \%$ & & \\
\hline $25-31$ & $38 \%$ & & $33 \%$ & & \\
\hline $32-38$ & $13 \%$ & & $21 \%$ & & \\
\hline \multirow[t]{2}{*}{$39-41$} & $1 \%$ & & $7 \%$ & & \\
\hline & & & & & $\begin{array}{l}\text { p-value for chi-sq test }= \\
0.000\end{array}$ \\
\hline Education & & 186 & & 29992 & \\
\hline Primary school & $4 \%$ & & $19 \%$ & & \\
\hline Intermediate & $0 \%$ & & $27 \%$ & & \\
\hline Secondary & $30 \%$ & & $36 \%$ & & \\
\hline Vocational & $8 \%$ & & $1 \%$ & & \\
\hline Post-secondary & $2 \%$ & & $8 \%$ & & \\
\hline $\begin{array}{l}\text { Academic } \\
\text { institute }\end{array}$ & $57 \%$ & & $9 \%$ & & \\
\hline \multirow[t]{2}{*}{ Other } & $0 \%$ & & $0 \%$ & & \\
\hline & & & & & $\begin{array}{l}\mathrm{p} \text {-value for chi-sq test }= \\
0.000\end{array}$ \\
\hline $\begin{array}{c}\text { Residence } \\
\text { Type }\end{array}$ & & 274 & & 30585 & \\
\hline Urban & $55 \%$ & & $33 \%$ & & \\
\hline Rural & $22 \%$ & & $54 \%$ & & \\
\hline \multirow[t]{2}{*}{ Refugee camps } & $23 \%$ & & $13 \%$ & & \\
\hline & & & & & $\begin{array}{l}\text { p-value for chi-sq test }= \\
0.000\end{array}$ \\
\hline
\end{tabular}




\begin{tabular}{|c|c|c|c|c|c|}
\hline Characteristics & $\begin{array}{l}\text { Hamas } \\
\text { and } \\
\text { PIJ } \\
\text { terrorists }\end{array}$ & $\begin{array}{c}\text { No. of } \\
\text { obs. }\end{array}$ & $\begin{array}{c}\text { Palestinian } \\
\text { population } \\
\text { Age 18-41 } \\
\text { Males and } \\
\text { Muslims }\end{array}$ & $\begin{array}{c}\text { No. of } \\
\text { obs. }\end{array}$ & \\
\hline $\begin{array}{c}\text { School } \\
\text { Enrollment } \\
\text { Status } \\
\end{array}$ & & 208 & & 30585 & \\
\hline $\begin{array}{l}\text { Studied } \\
\text { previously }\end{array}$ & $72 \%$ & & $88 \%$ & & \\
\hline $\begin{array}{l}\text { Presently } \\
\text { studies }\end{array}$ & $28 \%$ & & $10 \%$ & & \\
\hline Never studied & $0 \%$ & & $2 \%$ & & \\
\hline & & & & & $\begin{array}{l}\text { p-value for chi-sq test = } \\
0.000\end{array}$ \\
\hline Marital Status & & 214 & & 30585 & \\
\hline Married & $44 \%$ & & $60 \%$ & & \\
\hline Divorced & $0 \%$ & & $0 \%$ & & \\
\hline Widowed & $0 \%$ & & $0 \%$ & & \\
\hline Single & $56 \%$ & & $40 \%$ & & \\
\hline & & & & & $\begin{array}{l}\text { p-value for chi-sq test }= \\
0.000\end{array}$ \\
\hline $\begin{array}{c}\text { Labor Force } \\
\text { Status }\end{array}$ & & 130 & & 30583 & \\
\hline $\begin{array}{l}\text { Full-time } \\
\text { employment }\end{array}$ & $90 \%$ & & $64 \%$ & & \\
\hline $\begin{array}{l}\text { Part-time } \\
\text { employment }\end{array}$ & $4 \%$ & & $6 \%$ & & \\
\hline $\begin{array}{l}\text { Absent from } \\
\text { work }\end{array}$ & $0 \%$ & & $3 \%$ & & \\
\hline Unemployed & $0 \%$ & & $7 \%$ & & \\
\hline $\begin{array}{l}\text { Not part of } \\
\text { labor force }\end{array}$ & $6 \%$ & & $19 \%$ & & \\
\hline & & & & & $\begin{array}{l}\text { p-value for chi-sq test }= \\
0.000\end{array}$ \\
\hline $\begin{array}{l}\text { District of } \\
\text { Residence }\end{array}$ & & 273 & & 30585 & \\
\hline Gaza & $48 \%$ & & $22 \%$ & & \\
\hline Judea Samaria & $49 \%$ & & $78 \%$ & & \\
\hline Northern & $0 \%$ & & $0 \%$ & & \\
\hline Central & $0 \%$ & & $0 \%$ & & \\
\hline Southern & $0 \%$ & & $0 \%$ & & \\
\hline Jerusalem & $2 \%$ & & $0 \%$ & & $\begin{array}{l}\text { p-value for chi-sq test }= \\
0.000\end{array}$ \\
\hline
\end{tabular}

Chi-square test refers to a test of the null hypothesis that the characteristic is independent of Hamas and PIJ status. 


\section{$\underline{\text { Table } 1.3}$}

Characteristics of Palestinian (Hamas and PIJ) terrorists and Palestinian population of similar age, sex and religion - sample restricted: only individuals between 18-41 years of age were included, and 50 PIJ leaders deported on December 17, 1992 were not included.

\begin{tabular}{|c|c|c|c|c|c|}
\hline Characteristics & $\begin{array}{l}\text { Hamas } \\
\text { and } \\
\text { PIJ } \\
\text { terrorists }\end{array}$ & $\begin{array}{l}\text { No. of } \\
\text { obs. }\end{array}$ & $\begin{array}{c}\text { Palestinian } \\
\text { population } \\
\text { Age 18-41 } \\
\text { Males and } \\
\text { Muslims }\end{array}$ & $\begin{array}{l}\text { No. of } \\
\text { obs. }\end{array}$ & \\
\hline Poverty & & 163 & & 16195 & \\
\hline Poor & $20 \%$ & & $32 \%$ & & \\
\hline Average & $40 \%$ & & $48 \%$ & & \\
\hline Well & $30 \%$ & & $20 \%$ & & \\
\hline \multirow[t]{2}{*}{ Very Well } & $10 \%$ & & $0 \%$ & & \\
\hline & & & & & $\begin{array}{l}\text { p-value for chi-sq test }= \\
0.000\end{array}$ \\
\hline Age & & 230 & & 30585 & \\
\hline $18-24$ & $55 \%$ & & $39 \%$ & & \\
\hline $25-31$ & $36 \%$ & & $33 \%$ & & \\
\hline $32-38$ & $8 \%$ & & $21 \%$ & & \\
\hline \multirow{2}{*}{$39-41$} & $1 \%$ & & $7 \%$ & & \\
\hline & & & & & $\begin{array}{l}\text { p-value for chi-sq test }= \\
0.000\end{array}$ \\
\hline Education & & 144 & & 29992 & \\
\hline Primary school & $4 \%$ & & $19 \%$ & & \\
\hline Intermediate & $0 \%$ & & $27 \%$ & & \\
\hline Secondary & $38 \%$ & & $36 \%$ & & \\
\hline Vocational & $3 \%$ & & $1 \%$ & & \\
\hline Post-secondary & $2 \%$ & & $8 \%$ & & \\
\hline $\begin{array}{l}\text { Academic } \\
\text { institute }\end{array}$ & $53 \%$ & & $9 \%$ & & \\
\hline \multirow[t]{2}{*}{ Other } & $0 \%$ & & $0 \%$ & & \\
\hline & & & & & $\begin{array}{l}\text { p-value for chi-sq test }= \\
0.000\end{array}$ \\
\hline $\begin{array}{l}\text { Residence } \\
\text { Type }\end{array}$ & & 225 & & 30585 & \\
\hline Urban & $52 \%$ & & $33 \%$ & & \\
\hline Rural & $20 \%$ & & $54 \%$ & & \\
\hline \multirow[t]{2}{*}{ Refugee camps } & $28 \%$ & & $13 \%$ & & \\
\hline & & & & & $\begin{array}{l}\text { p-value for chi-sq test }= \\
0.000\end{array}$ \\
\hline
\end{tabular}




\begin{tabular}{|c|c|c|c|c|c|}
\hline Characteristics & $\begin{array}{l}\text { Hamas } \\
\text { and } \\
\text { PIJ } \\
\text { terrorists }\end{array}$ & $\begin{array}{c}\text { No. of } \\
\text { obs. }\end{array}$ & $\begin{array}{c}\text { Palestinian } \\
\text { population } \\
\text { Age 18-41 } \\
\text { Males and } \\
\text { Muslims }\end{array}$ & $\begin{array}{c}\text { No. of } \\
\text { obs. }\end{array}$ & \\
\hline $\begin{array}{c}\text { School } \\
\text { Enrollment } \\
\text { Status } \\
\end{array}$ & & 164 & & 30585 & \\
\hline $\begin{array}{l}\text { Studied } \\
\text { previously }\end{array}$ & $69 \%$ & & $88 \%$ & & \\
\hline $\begin{array}{l}\text { Presently } \\
\text { studies }\end{array}$ & $31 \%$ & & $10 \%$ & & \\
\hline Never studied & $0 \%$ & & $2 \%$ & & \\
\hline & & & & & $\begin{array}{l}\text { p-value for chi-sq test = } \\
0.000\end{array}$ \\
\hline Marital Status & & 214 & & 30585 & \\
\hline Married & $33 \%$ & & $60 \%$ & & \\
\hline Divorced & $0 \%$ & & $0 \%$ & & \\
\hline Widowed & $0 \%$ & & $0 \%$ & & \\
\hline Single & $67 \%$ & & $40 \%$ & & \\
\hline & & & & & $\begin{array}{l}\text { p-value for chi-sq test }= \\
0.000\end{array}$ \\
\hline $\begin{array}{l}\text { Labor Force } \\
\text { Status }\end{array}$ & & 92 & & 30583 & \\
\hline $\begin{array}{l}\text { Full-time } \\
\text { employment }\end{array}$ & $88 \%$ & & $64 \%$ & & \\
\hline $\begin{array}{l}\text { Part-time } \\
\text { employment }\end{array}$ & $5 \%$ & & $6 \%$ & & \\
\hline $\begin{array}{l}\text { Absent from } \\
\text { work }\end{array}$ & $0 \%$ & & $3 \%$ & & \\
\hline Unemployed & $0 \%$ & & $7 \%$ & & \\
\hline $\begin{array}{l}\text { Not part of } \\
\text { labor force }\end{array}$ & $7 \%$ & & $19 \%$ & & \\
\hline & & & & & $\begin{array}{l}\text { p-value for chi-sq test }= \\
0.000\end{array}$ \\
\hline $\begin{array}{l}\text { District of } \\
\text { Residence }\end{array}$ & & 224 & & 30585 & \\
\hline Gaza & $53 \%$ & & $22 \%$ & & \\
\hline Judea Samaria & $43 \%$ & & $78 \%$ & & \\
\hline Northern & $0 \%$ & & $0 \%$ & & \\
\hline Central & $0 \%$ & & $0 \%$ & & \\
\hline Southern & $0 \%$ & & $0 \%$ & & \\
\hline Jerusalem & $3 \%$ & & $0 \%$ & & $\begin{array}{l}\text { p-value for chi-sq test }= \\
0.000\end{array}$ \\
\hline
\end{tabular}

Chi-square test refers to a test of the null hypothesis that the characteristic is independent of Hamas and PIJ status. 


\section{$\underline{\text { Table 2.1 }}$}

Characteristics of Hamas and PIJ Palestinian Suicide bombers and Palestinian population of similar age, sex and religion.

\begin{tabular}{|c|c|c|c|c|c|}
\hline Characteristics & $\begin{array}{l}\text { Suicide } \\
\text { bombers }\end{array}$ & $\begin{array}{l}\text { No. of } \\
\text { obs. }\end{array}$ & $\begin{array}{c}\text { Palestinian } \\
\text { population } \\
\text { Age 16-50 } \\
\text { Males and } \\
\text { Muslims }\end{array}$ & $\begin{array}{l}\text { No. of } \\
\text { obs. }\end{array}$ & \\
\hline Poverty & & 48 & & 18803 & \\
\hline Poor & $13 \%$ & & $32 \%$ & & \\
\hline Average & $54 \%$ & & $48 \%$ & & \\
\hline Well & $25 \%$ & & $20 \%$ & & \\
\hline \multirow{2}{*}{ Very Well } & $8 \%$ & & $0 \%$ & & \\
\hline & & & & & $\begin{array}{l}p \text {-value for chi-sq test }= \\
0.000\end{array}$ \\
\hline Age & & 63 & & 38875 & \\
\hline $15-17$ & $8 \%$ & & $13 \%$ & & \\
\hline $18-24$ & $67 \%$ & & $30 \%$ & & \\
\hline $25-34$ & $22 \%$ & & $33 \%$ & & \\
\hline $35-44$ & $0 \%$ & & $18 \%$ & & \\
\hline \multirow[t]{2}{*}{$45-50$} & $3 \%$ & & $6 \%$ & & \\
\hline & & & & & $\begin{array}{l}\text { p-value for chi-sq test }= \\
0.000\end{array}$ \\
\hline Education & & 44 & & 37824 & \\
\hline Primary school & $2 \%$ & & $20 \%$ & & \\
\hline Intermediate & $0 \%$ & & $28 \%$ & & \\
\hline Secondary & $36 \%$ & & $36 \%$ & & \\
\hline Vocational & $5 \%$ & & $1 \%$ & & \\
\hline Post-secondary & $2 \%$ & & $7 \%$ & & \\
\hline \multirow[t]{2}{*}{$\begin{array}{l}\text { Academic } \\
\text { institute }\end{array}$} & $55 \%$ & & $8 \%$ & & \\
\hline & & & & & $\begin{array}{l}\text { p-value for chi-sq test }= \\
0.000\end{array}$ \\
\hline $\begin{array}{c}\text { Residence } \\
\text { Type }\end{array}$ & & 64 & & 38875 & \\
\hline Urban & $53 \%$ & & $34 \%$ & & \\
\hline Rural & $17 \%$ & & $54 \%$ & & \\
\hline \multirow[t]{2}{*}{ Refugee camps } & $30 \%$ & & $13 \%$ & & \\
\hline & & & & & $\begin{array}{l}p \text {-value for chi-sq test }= \\
0.000\end{array}$ \\
\hline
\end{tabular}




\begin{tabular}{|c|c|c|c|c|c|}
\hline Characteristics & $\begin{array}{c}\text { Suicide } \\
\text { bombers }\end{array}$ & $\begin{array}{l}\text { No. of } \\
\text { obs. }\end{array}$ & $\begin{array}{c}\text { Palestinian } \\
\text { population } \\
\text { Age 16-50 } \\
\text { Males and } \\
\text { Muslims }\end{array}$ & $\begin{array}{l}\text { No. of } \\
\text { obs. }\end{array}$ & \\
\hline $\begin{array}{c}\text { School } \\
\text { Enrollment } \\
\text { Status }\end{array}$ & & 48 & & 38875 & \\
\hline $\begin{array}{l}\text { Studied } \\
\text { previously }\end{array}$ & $50 \%$ & & $83 \%$ & & \\
\hline $\begin{array}{l}\text { Presently } \\
\text { studies }\end{array}$ & $50 \%$ & & $15 \%$ & & \\
\hline Never studied & $0 \%$ & & $3 \%$ & & \\
\hline & & & & & $\begin{array}{l}p \text {-value for chi-sq test }= \\
0.000\end{array}$ \\
\hline Marital Status & & 50 & & 38875 & \\
\hline Married & $16 \%$ & & $58 \%$ & & \\
\hline Divorced & $0 \%$ & & $0 \%$ & & \\
\hline Widowed & $0 \%$ & & $0 \%$ & & \\
\hline Single & $84 \%$ & & $42 \%$ & & \\
\hline & & & & & $\begin{array}{l}p \text {-value for chi-sq test }= \\
0.000\end{array}$ \\
\hline $\begin{array}{c}\text { Labor Force } \\
\text { Status }\end{array}$ & & 24 & & 38872 & \\
\hline $\begin{array}{l}\text { Full-time } \\
\text { employment }\end{array}$ & $96 \%$ & & $61 \%$ & & \\
\hline $\begin{array}{l}\text { Part-time } \\
\text { employment }\end{array}$ & $0 \%$ & & $6 \%$ & & \\
\hline $\begin{array}{l}\text { Absent from } \\
\text { work }\end{array}$ & $0 \%$ & & $3 \%$ & & \\
\hline Unemployed & $0 \%$ & & $6 \%$ & & \\
\hline $\begin{array}{l}\text { Not part of } \\
\text { labor force }\end{array}$ & $4 \%$ & & $24 \%$ & & \\
\hline & & & & & $\begin{array}{l}\text { p-value for chi-sq test = } \\
0.013\end{array}$ \\
\hline $\begin{array}{l}\text { District of } \\
\text { Residence }\end{array}$ & & 62 & & 38875 & \\
\hline Gaza & $45 \%$ & & $22 \%$ & & \\
\hline Judea Samaria & $47 \%$ & & $78 \%$ & & \\
\hline Northern & $2 \%$ & & $0 \%$ & & \\
\hline Central & $0 \%$ & & $0 \%$ & & \\
\hline Southern & $0 \%$ & & $0 \%$ & & \\
\hline Jerusalem & $7 \%$ & & $0 \%$ & & $\begin{array}{l}\text { p-value for chi-sq test }= \\
0.000\end{array}$ \\
\hline
\end{tabular}

Chi-square test refers to a test of the null hypothesis that the characteristic is independent of Suicide bomber status. 


\section{Table 2.2}

Characteristics of Hamas and PIJ Palestinian Suicide bombers and Palestinian population of similar age, sex and religion - sample restricted: only individuals between 17-28 years of age were included.

\begin{tabular}{|c|c|c|c|c|c|}
\hline Characteristics & $\begin{array}{c}\text { Suicide } \\
\text { bombers }\end{array}$ & $\begin{array}{l}\text { No. of } \\
\text { obs. }\end{array}$ & $\begin{array}{c}\text { Palestinian } \\
\text { population } \\
\text { Age 17-28 } \\
\text { Males and } \\
\text { Muslims }\end{array}$ & $\begin{array}{l}\text { No. of } \\
\text { obs. }\end{array}$ & \\
\hline Poverty & & 45 & & 8947 & \\
\hline Poor & $13 \%$ & & $40 \%$ & & \\
\hline Average & $56 \%$ & & $45 \%$ & & \\
\hline Well & $24 \%$ & & $15 \%$ & & \\
\hline \multirow[t]{2}{*}{ Very Well } & $7 \%$ & & $0 \%$ & & \\
\hline & & & & & $\begin{array}{l}\text { p-value for chi-sq test }= \\
0.000\end{array}$ \\
\hline Age & & 57 & & 19905 & \\
\hline $17-20$ & $33 \%$ & & $40 \%$ & & \\
\hline $21-24$ & $47 \%$ & & $30 \%$ & & \\
\hline \multirow[t]{2}{*}{$25-28$} & $19 \%$ & & $30 \%$ & & \\
\hline & & & & & $\begin{array}{l}\text { p-value for chi-sq test }= \\
0.018\end{array}$ \\
\hline Education & & 42 & & 19593 & \\
\hline Primary school & $2 \%$ & & $15 \%$ & & \\
\hline Intermediate & $0 \%$ & & $26 \%$ & & \\
\hline Secondary & $38 \%$ & & $44 \%$ & & \\
\hline Vocational & $5 \%$ & & $1 \%$ & & \\
\hline Post-secondary & $2 \%$ & & $5 \%$ & & \\
\hline \multirow[t]{2}{*}{$\begin{array}{l}\text { Academic } \\
\text { institute }\end{array}$} & $52 \%$ & & $7 \%$ & & \\
\hline & & & & & $\begin{array}{l}\text { p-value for chi-sq test }= \\
0.000\end{array}$ \\
\hline $\begin{array}{c}\text { Residence } \\
\text { Type }\end{array}$ & & 55 & & 19905 & \\
\hline Urban & $53 \%$ & & $32 \%$ & & \\
\hline Rural & $13 \%$ & & $55 \%$ & & \\
\hline \multirow{2}{*}{ Refugee camps } & $35 \%$ & & $13 \%$ & & \\
\hline & & & & & $\begin{array}{l}\text { p-value for chi-sq test }= \\
0.000\end{array}$ \\
\hline
\end{tabular}




\begin{tabular}{|c|c|c|c|c|c|}
\hline Characteristics & $\begin{array}{c}\text { Suicide } \\
\text { bombers }\end{array}$ & $\begin{array}{l}\text { No. of } \\
\text { obs. }\end{array}$ & $\begin{array}{c}\text { Palestinian } \\
\text { population } \\
\text { Age 17-28 } \\
\text { Males and } \\
\text { Muslims }\end{array}$ & $\begin{array}{l}\text { No. of } \\
\text { obs. }\end{array}$ & \\
\hline $\begin{array}{c}\text { School } \\
\text { Enrollment } \\
\text { Status }\end{array}$ & & 45 & & 19905 & \\
\hline $\begin{array}{l}\text { Studied } \\
\text { previously }\end{array}$ & $47 \%$ & & $77 \%$ & & \\
\hline $\begin{array}{l}\text { Presently } \\
\text { studies }\end{array}$ & $53 \%$ & & $22 \%$ & & \\
\hline Never studied & $0 \%$ & & $1 \%$ & & \\
\hline & & & & & $\begin{array}{l}p \text {-value for chi-sq test }= \\
0.000\end{array}$ \\
\hline Marital Status & & 46 & & 19905 & \\
\hline Married & $11 \%$ & & $33 \%$ & & \\
\hline Divorced & $0 \%$ & & $0 \%$ & & \\
\hline Widowed & $0 \%$ & & $0 \%$ & & \\
\hline Single & $89 \%$ & & $67 \%$ & & \\
\hline & & & & & $\begin{array}{l}\mathrm{p} \text {-value for chi-sq test }= \\
0.020\end{array}$ \\
\hline $\begin{array}{c}\text { Labor Force } \\
\text { Status }\end{array}$ & & 21 & & 19903 & \\
\hline $\begin{array}{l}\text { Full-time } \\
\text { employment }\end{array}$ & $95 \%$ & & $52 \%$ & & \\
\hline $\begin{array}{l}\text { Part-time } \\
\text { employment }\end{array}$ & $0 \%$ & & $6 \%$ & & \\
\hline $\begin{array}{l}\text { Absent from } \\
\text { work }\end{array}$ & $0 \%$ & & $3 \%$ & & \\
\hline Unemployed & $0 \%$ & & $8 \%$ & & \\
\hline $\begin{array}{l}\text { Not part of } \\
\text { labor force }\end{array}$ & $5 \%$ & & $31 \%$ & & \\
\hline & & & & & $\begin{array}{l}\text { p-value for chi-sq test }= \\
0.003\end{array}$ \\
\hline $\begin{array}{l}\text { District of } \\
\text { Residence }\end{array}$ & & 53 & & 19905 & \\
\hline Gaza & $51 \%$ & & $21 \%$ & & \\
\hline Judea Samaria & $47 \%$ & & $79 \%$ & & \\
\hline Northern & $0 \%$ & & $0 \%$ & & \\
\hline Central & $0 \%$ & & $0 \%$ & & \\
\hline Southern & $0 \%$ & & $0 \%$ & & \\
\hline Jerusalem & $2 \%$ & & $0 \%$ & & $\begin{array}{l}\text { p-value for chi-sq test }= \\
0.000\end{array}$ \\
\hline
\end{tabular}

Chi-square test refers to a test of the null hypothesis that the characteristic is independent of Suicide bomber status. 


\section{Table 3.1}

Characteristics of Hamas terrorists and Palestinian population of similar age, sex and religion.

\begin{tabular}{|c|c|c|c|c|c|}
\hline Characteristics & $\begin{array}{l}\text { Hamas } \\
\text { terrorists }\end{array}$ & $\begin{array}{l}\text { No. of } \\
\text { obs. }\end{array}$ & $\begin{array}{c}\text { Palestinian } \\
\text { population } \\
\text { Age 16-50 } \\
\text { Males and } \\
\text { Muslims }\end{array}$ & $\begin{array}{l}\text { No. of } \\
\text { obs. }\end{array}$ & \\
\hline Poverty & & 134 & & 18803 & \\
\hline Poor & $16 \%$ & & $32 \%$ & & \\
\hline Average & $40 \%$ & & $48 \%$ & & \\
\hline Well & $31 \%$ & & $20 \%$ & & \\
\hline \multirow[t]{2}{*}{ Very Well } & $13 \%$ & & $0 \%$ & & \\
\hline & & & & & $\begin{array}{l}\text { p-value for chi-sq test }= \\
0.000\end{array}$ \\
\hline Age & & 170 & & 38875 & \\
\hline $15-17$ & $2 \%$ & & $13 \%$ & & \\
\hline $18-24$ & $49 \%$ & & $30 \%$ & & \\
\hline $25-34$ & $40 \%$ & & $33 \%$ & & \\
\hline $35-44$ & $8 \%$ & & $18 \%$ & & \\
\hline \multirow[t]{2}{*}{$45-50$} & $1 \%$ & & $6 \%$ & & \\
\hline & & & & & $\begin{array}{l}\text { p-value for chi-sq test }= \\
0.000\end{array}$ \\
\hline Education & & 117 & & 37824 & \\
\hline Primary school & $2 \%$ & & $20 \%$ & & \\
\hline Intermediate & $0 \%$ & & $28 \%$ & & \\
\hline Secondary & $35 \%$ & & $36 \%$ & & \\
\hline Vocational & $3 \%$ & & $1 \%$ & & \\
\hline Post-secondary & $3 \%$ & & $7 \%$ & & \\
\hline $\begin{array}{l}\text { Academic } \\
\text { institute }\end{array}$ & $58 \%$ & & $8 \%$ & & \\
\hline \multirow[t]{2}{*}{ Other } & $0 \%$ & & $0 \%$ & & \\
\hline & & & & & $\begin{array}{l}\text { p-value for chi-sq test }= \\
0.000\end{array}$ \\
\hline $\begin{array}{c}\text { Residence } \\
\text { Type }\end{array}$ & & 177 & & 38875 & \\
\hline Urban & $54 \%$ & & $34 \%$ & & \\
\hline Rural & $20 \%$ & & $54 \%$ & & \\
\hline \multirow[t]{2}{*}{ Refugee camps } & $27 \%$ & & $13 \%$ & & \\
\hline & & & & & $\begin{array}{l}\text { p-value for chi-sq test = } \\
0.000\end{array}$ \\
\hline
\end{tabular}




\begin{tabular}{|c|c|c|c|c|c|}
\hline Characteristics & $\begin{array}{l}\text { Hamas } \\
\text { terrorists }\end{array}$ & $\begin{array}{c}\text { No. of } \\
\text { obs. }\end{array}$ & $\begin{array}{c}\text { Palestinian } \\
\text { population } \\
\text { Age 16-50 } \\
\text { Males and } \\
\text { Muslims }\end{array}$ & $\begin{array}{c}\begin{array}{c}\text { No. of } \\
\text { obs. }\end{array}\end{array}$ & \\
\hline $\begin{array}{c}\text { School } \\
\text { Enrollment } \\
\text { Status } \\
\end{array}$ & & 132 & & 38875 & \\
\hline $\begin{array}{l}\text { Studied } \\
\text { previously }\end{array}$ & $67 \%$ & & $83 \%$ & & \\
\hline $\begin{array}{l}\text { Presently } \\
\text { studies }\end{array}$ & $33 \%$ & & $15 \%$ & & \\
\hline Never studied & $0 \%$ & & $3 \%$ & & \\
\hline & & & & & $\begin{array}{l}\text { p-value for chi-sq test }= \\
0.000\end{array}$ \\
\hline Marital Status & & 129 & & 38875 & \\
\hline Married & $35 \%$ & & $58 \%$ & & \\
\hline Divorced & $0 \%$ & & $0 \%$ & & \\
\hline Widowed & $0 \%$ & & $0 \%$ & & \\
\hline Single & $65 \%$ & & $42 \%$ & & \\
\hline & & & & & $\begin{array}{l}\text { p-value for chi-sq test }= \\
0.000\end{array}$ \\
\hline $\begin{array}{l}\text { Labor Force } \\
\text { Status }\end{array}$ & & 78 & & 38872 & \\
\hline $\begin{array}{l}\text { Full-time } \\
\text { employment }\end{array}$ & $87 \%$ & & $61 \%$ & & \\
\hline $\begin{array}{l}\text { Part-time } \\
\text { employment }\end{array}$ & $5 \%$ & & $6 \%$ & & \\
\hline $\begin{array}{l}\text { Absent from } \\
\text { work }\end{array}$ & $0 \%$ & & $3 \%$ & & \\
\hline Unemployed & $0 \%$ & & $6 \%$ & & \\
\hline $\begin{array}{l}\text { Not part of } \\
\text { labor force }\end{array}$ & $8 \%$ & & $24 \%$ & & \\
\hline & & & & & $\begin{array}{l}\text { p-value for chi-sq test }= \\
0.000\end{array}$ \\
\hline $\begin{array}{l}\text { District of } \\
\text { Residence }\end{array}$ & & 178 & & 38875 & \\
\hline Gaza & $49 \%$ & & $22 \%$ & & \\
\hline Judea Samaria & $44 \%$ & & $78 \%$ & & \\
\hline Northern & $2 \%$ & & $0 \%$ & & \\
\hline Central & $0 \%$ & & $0 \%$ & & \\
\hline Southern & $0 \%$ & & $0 \%$ & & \\
\hline Jerusalem & $4 \%$ & & $0 \%$ & & $\begin{array}{l}\text { p-value for chi-sq test }= \\
0.000\end{array}$ \\
\hline
\end{tabular}

Chi-square test refers to a test of the null hypothesis that the characteristic is independent of Hamas status. 


\section{Table 3.2}

Characteristics of Hamas terrorists and Palestinian population of similar age, sex and religion - sample restricted: only individuals between 18-41 years of age were included.

\begin{tabular}{|c|c|c|c|c|c|}
\hline Characteristics & $\begin{array}{l}\text { Hamas } \\
\text { terrorists }\end{array}$ & $\begin{array}{l}\text { No. of } \\
\text { obs. }\end{array}$ & $\begin{array}{c}\text { Palestinian } \\
\text { population } \\
\text { Age 18-41 } \\
\text { Males and } \\
\text { Muslims }\end{array}$ & $\begin{array}{l}\text { No. of } \\
\text { obs. }\end{array}$ & \\
\hline Poverty & & 120 & & 16195 & \\
\hline Poor & $17 \%$ & & $32 \%$ & & \\
\hline Average & $39 \%$ & & $48 \%$ & & \\
\hline Well & $31 \%$ & & $20 \%$ & & \\
\hline \multirow[t]{2}{*}{ Very Well } & $13 \%$ & & $0 \%$ & & \\
\hline & & & & & $\begin{array}{l}\text { p-value for chi-sq test }= \\
0.000\end{array}$ \\
\hline Age & & 163 & & 30585 & \\
\hline $18-24$ & $50 \%$ & & $39 \%$ & & \\
\hline $25-31$ & $40 \%$ & & $33 \%$ & & \\
\hline $32-38$ & $9 \%$ & & $21 \%$ & & \\
\hline \multirow[t]{2}{*}{$39-41$} & $1 \%$ & & $7 \%$ & & \\
\hline & & & & & $\begin{array}{l}\text { p-value for chi-sq test }= \\
0.000\end{array}$ \\
\hline Education & & 102 & & 29954 & \\
\hline Primary school & $2 \%$ & & $19 \%$ & & \\
\hline Intermediate & $0 \%$ & & $27 \%$ & & \\
\hline Secondary & $33 \%$ & & $36 \%$ & & \\
\hline Vocational & $3 \%$ & & $1 \%$ & & \\
\hline Post-secondary & $3 \%$ & & $8 \%$ & & \\
\hline \multirow[t]{2}{*}{$\begin{array}{l}\text { Academic } \\
\text { institute }\end{array}$} & $59 \%$ & & $9 \%$ & & \\
\hline & & & & & $\begin{array}{l}\text { p-value for chi-sq test }= \\
0.000\end{array}$ \\
\hline $\begin{array}{c}\text { Residence } \\
\text { Type }\end{array}$ & & 159 & & 30585 & \\
\hline Urban & $52 \%$ & & $33 \%$ & & \\
\hline Rural & $20 \%$ & & $54 \%$ & & \\
\hline Refugee camps & $28 \%$ & & $13 \%$ & & \\
\hline & & & & & $\begin{array}{l}p \text {-value for chi-sq test }= \\
0.000\end{array}$ \\
\hline
\end{tabular}




\begin{tabular}{|c|c|c|c|c|c|}
\hline Characteristics & $\begin{array}{l}\text { Hamas } \\
\text { terrorists }\end{array}$ & $\begin{array}{l}\text { No. of } \\
\text { obs. }\end{array}$ & $\begin{array}{c}\text { Palestinian } \\
\text { population } \\
\text { Age 18-41 } \\
\text { Males and } \\
\text { Muslims }\end{array}$ & $\begin{array}{l}\text { No. of } \\
\text { obs. }\end{array}$ & \\
\hline $\begin{array}{c}\text { School } \\
\text { Enrollment } \\
\text { Status } \\
\end{array}$ & & 117 & & 30585 & \\
\hline $\begin{array}{l}\text { Studied } \\
\text { previously }\end{array}$ & $66 \%$ & & $88 \%$ & & \\
\hline $\begin{array}{l}\text { Presently } \\
\text { studies }\end{array}$ & $34 \%$ & & $10 \%$ & & \\
\hline Never studied & $0 \%$ & & $2 \%$ & & \\
\hline & & & & & $\begin{array}{l}\text { p-value for chi-sq test }= \\
0.000\end{array}$ \\
\hline Marital Status & & 115 & & 30585 & \\
\hline Married & $33 \%$ & & $60 \%$ & & \\
\hline Divorced & $0 \%$ & & $0 \%$ & & \\
\hline Widowed & $0 \%$ & & $0 \%$ & & \\
\hline Single & $67 \%$ & & $40 \%$ & & \\
\hline & & & & & $\begin{array}{l}\text { p-value for chi-sq test }= \\
0.000\end{array}$ \\
\hline $\begin{array}{l}\text { Labor Force } \\
\text { Status }\end{array}$ & & 70 & & 30583 & \\
\hline $\begin{array}{l}\text { Full-time } \\
\text { employment }\end{array}$ & $87 \%$ & & $64 \%$ & & \\
\hline $\begin{array}{l}\text { Part-time } \\
\text { employment }\end{array}$ & $4 \%$ & & $6 \%$ & & \\
\hline $\begin{array}{l}\text { Absent from } \\
\text { work }\end{array}$ & $0 \%$ & & $3 \%$ & & \\
\hline Unemployed & $0 \%$ & & $7 \%$ & & \\
\hline $\begin{array}{l}\text { Not part of } \\
\text { labor force }\end{array}$ & $9 \%$ & & $19 \%$ & & \\
\hline & & & & & $\begin{array}{l}\text { p-value for chi-sq test }= \\
0.001\end{array}$ \\
\hline $\begin{array}{l}\text { District of } \\
\text { Residence }\end{array}$ & & 160 & & 30585 & \\
\hline Gaza & $50 \%$ & & $22 \%$ & & \\
\hline Judea Samaria & $45 \%$ & & $78 \%$ & & \\
\hline Northern & $1 \%$ & & $0 \%$ & & \\
\hline Central & $1 \%$ & & $0 \%$ & & \\
\hline Southern & $1 \%$ & & $0 \%$ & & \\
\hline Jerusalem & $3 \%$ & & $0 \%$ & & $\begin{array}{l}\text { p-value for chi-sq test }= \\
0.000\end{array}$ \\
\hline
\end{tabular}

Chi-square test refers to a test of the null hypothesis that the characteristic is independent of Hamas status. 


\section{$\underline{\text { Table } 4.1}$}

Characteristics of Palestinian Islamic Jihad terrorists and Palestinian population of similar age, sex and religion.

\begin{tabular}{|c|c|c|c|c|c|}
\hline Characteristics & $\begin{array}{c}\text { PIJ } \\
\text { terrorists }\end{array}$ & $\begin{array}{l}\text { No. of } \\
\text { obs. }\end{array}$ & $\begin{array}{c}\text { Palestinian } \\
\text { population } \\
\text { Age 15-56 } \\
\text { Males and } \\
\text { Muslims }\end{array}$ & $\begin{array}{l}\text { No. of } \\
\text { obs. }\end{array}$ & \\
\hline Poverty & & 97 & & 19590 & \\
\hline Poor & $14 \%$ & & $31 \%$ & & \\
\hline Average & $44 \%$ & & $48 \%$ & & \\
\hline Well & $36 \%$ & & $20 \%$ & & \\
\hline \multirow{2}{*}{ Very Well } & $5 \%$ & & $0 \%$ & & \\
\hline & & & & & $\begin{array}{l}\text { p-value for chi-sq test }= \\
0.000\end{array}$ \\
\hline Age & & 126 & & 41762 & \\
\hline $15-17$ & $6 \%$ & & $12 \%$ & & \\
\hline $18-24$ & $40 \%$ & & $28 \%$ & & \\
\hline $25-34$ & $44 \%$ & & $32 \%$ & & \\
\hline $35-44$ & $8 \%$ & & $17 \%$ & & \\
\hline $45-54$ & $1 \%$ & & $9 \%$ & & \\
\hline \multirow[t]{2}{*}{$55-56$} & $1 \%$ & & $1 \%$ & & \\
\hline & & & & & $\begin{array}{l}\text { p-value for chi-sq test }= \\
0.000\end{array}$ \\
\hline Education & & 92 & & 40278 & \\
\hline Primary school & $7 \%$ & & $21 \%$ & & \\
\hline Intermediate & $0 \%$ & & $28 \%$ & & \\
\hline Secondary & $26 \%$ & & $35 \%$ & & \\
\hline Vocational & $14 \%$ & & $1 \%$ & & \\
\hline Post-secondary & $0 \%$ & & $6 \%$ & & \\
\hline $\begin{array}{l}\text { Academic } \\
\text { institute }\end{array}$ & $53 \%$ & & $8 \%$ & & \\
\hline \multirow[t]{2}{*}{ Other } & $0 \%$ & & $0 \%$ & & \\
\hline & & & & & $\begin{array}{l}\text { p-value for chi-sq test }= \\
0.000\end{array}$ \\
\hline $\begin{array}{c}\text { Residence } \\
\text { Type }\end{array}$ & & 135 & & 41762 & \\
\hline Urban & $54 \%$ & & $34 \%$ & & \\
\hline Rural & $26 \%$ & & $54 \%$ & & \\
\hline \multirow[t]{2}{*}{ Refugee camps } & $20 \%$ & & $13 \%$ & & \\
\hline & & & & & $\begin{array}{l}\text { p-value for chi-sq test }= \\
0.000\end{array}$ \\
\hline
\end{tabular}




\begin{tabular}{|c|c|c|c|c|c|}
\hline Characteristics & $\begin{array}{c}\text { PIJ } \\
\text { terrorists }\end{array}$ & $\begin{array}{l}\text { No. of } \\
\text { obs. }\end{array}$ & $\begin{array}{c}\text { Palestinian } \\
\text { population } \\
\text { Age 15-56 } \\
\text { Males and } \\
\text { Muslims }\end{array}$ & $\begin{array}{l}\text { No. of } \\
\text { obs. }\end{array}$ & \\
\hline $\begin{array}{c}\text { School } \\
\text { Enrollment } \\
\text { Status }\end{array}$ & & 100 & & 41762 & \\
\hline $\begin{array}{l}\text { Studied } \\
\text { previously }\end{array}$ & $77 \%$ & & $81 \%$ & & \\
\hline $\begin{array}{l}\text { Presently } \\
\text { studies }\end{array}$ & $23 \%$ & & $16 \%$ & & \\
\hline Never studied & $0 \%$ & & $3 \%$ & & \\
\hline & & & & & $\begin{array}{l}\mathrm{p} \text {-value for chi-sq test }= \\
0.031\end{array}$ \\
\hline Marital Status & & 110 & & 41762 & \\
\hline Married & $55 \%$ & & $59 \%$ & & \\
\hline Divorced & $0 \%$ & & $0 \%$ & & \\
\hline Widowed & $0 \%$ & & $0 \%$ & & \\
\hline Single & $45 \%$ & & $41 \%$ & & \\
\hline & & & & & $\begin{array}{l}\mathrm{p} \text {-value for chi-sq test }= \\
0.879\end{array}$ \\
\hline $\begin{array}{c}\text { Labor Force } \\
\text { Status }\end{array}$ & & 64 & & 41759 & \\
\hline $\begin{array}{l}\text { Full-time } \\
\text { employment }\end{array}$ & $94 \%$ & & $60 \%$ & & \\
\hline $\begin{array}{l}\text { Part-time } \\
\text { employment }\end{array}$ & $3 \%$ & & $6 \%$ & & \\
\hline $\begin{array}{l}\text { Absent from } \\
\text { work }\end{array}$ & $0 \%$ & & $3 \%$ & & \\
\hline Unemployed & $0 \%$ & & $6 \%$ & & \\
\hline $\begin{array}{l}\text { Not part of } \\
\text { labor force }\end{array}$ & $3 \%$ & & $25 \%$ & & \\
\hline & & & & & $\begin{array}{l}\text { p-value for chi-sq test }= \\
0.000\end{array}$ \\
\hline $\begin{array}{l}\text { District of } \\
\text { Residence }\end{array}$ & & 129 & & 41762 & \\
\hline Gaza & $45 \%$ & & $22 \%$ & & \\
\hline Judea Samaria & $54 \%$ & & $78 \%$ & & \\
\hline Northern & $0 \%$ & & $0 \%$ & & \\
\hline Central & $0 \%$ & & $0 \%$ & & \\
\hline Southern & $0 \%$ & & $0 \%$ & & \\
\hline Jerusalem & $1 \%$ & & $0 \%$ & & $\begin{array}{l}\text { p-value for chi-sq test }= \\
0.000\end{array}$ \\
\hline
\end{tabular}

Chi-square test refers to a test of the null hypothesis that the characteristic is independent of PIJ status. 


\section{Table 4.2}

Characteristics of Palestinian Islamic Jihad terrorists and Palestinian population of similar age, sex and religion - sample restricted: only individuals between 18-41 years of age were included.

\begin{tabular}{|c|c|c|c|c|c|}
\hline Characteristics & $\begin{array}{c}\text { PIJ } \\
\text { terrorists }\end{array}$ & $\begin{array}{l}\text { No. of } \\
\text { obs. }\end{array}$ & $\begin{array}{c}\text { Palestinian } \\
\text { population } \\
\text { Age 18-41 } \\
\text { Males and } \\
\text { Muslims }\end{array}$ & $\begin{array}{l}\text { No. of } \\
\text { obs. }\end{array}$ & \\
\hline Poverty & & 88 & & 16195 & \\
\hline Poor & $16 \%$ & & $32 \%$ & & \\
\hline Average & $43 \%$ & & $48 \%$ & & \\
\hline Well & $35 \%$ & & $20 \%$ & & \\
\hline \multirow[t]{2}{*}{ Very Well } & $6 \%$ & & $0 \%$ & & \\
\hline & & & & & $\begin{array}{l}\text { p-value for chi-sq test }= \\
0.000\end{array}$ \\
\hline Age & & 116 & & 30585 & \\
\hline $18-24$ & $44 \%$ & & $39 \%$ & & \\
\hline $25-31$ & $35 \%$ & & $33 \%$ & & \\
\hline $32-38$ & $19 \%$ & & $21 \%$ & & \\
\hline \multirow[t]{2}{*}{$39-41$} & $2 \%$ & & $7 \%$ & & \\
\hline & & & & & $\begin{array}{l}\text { p-value for chi-sq test }= \\
0.130\end{array}$ \\
\hline Education & & 84 & & 29954 & \\
\hline Primary school & $6 \%$ & & $19 \%$ & & \\
\hline Intermediate & $0 \%$ & & $27 \%$ & & \\
\hline Secondary & $26 \%$ & & $36 \%$ & & \\
\hline Vocational & $13 \%$ & & $1 \%$ & & \\
\hline Post-secondary & $0 \%$ & & $8 \%$ & & \\
\hline \multirow[t]{2}{*}{$\begin{array}{l}\text { Academic } \\
\text { institute }\end{array}$} & $55 \%$ & & $9 \%$ & & \\
\hline & & & & & $\begin{array}{l}\text { p-value for chi-sq test }= \\
0.000\end{array}$ \\
\hline $\begin{array}{c}\text { Residence } \\
\text { Type }\end{array}$ & & 115 & & 30585 & \\
\hline Urban & $58 \%$ & & $33 \%$ & & \\
\hline Rural & $26 \%$ & & $54 \%$ & & \\
\hline Refugee camps & $16 \%$ & & $13 \%$ & & \\
\hline & & & & & $\begin{array}{l}\text { p-value for chi-sq test }= \\
0.000\end{array}$ \\
\hline
\end{tabular}




\begin{tabular}{|c|c|c|c|c|c|}
\hline Characteristics & $\begin{array}{c}\text { PIJ } \\
\text { terrorists }\end{array}$ & $\begin{array}{l}\text { No. of } \\
\text { obs. }\end{array}$ & $\begin{array}{c}\text { Palestinian } \\
\text { population } \\
\text { Age 18-41 } \\
\text { Males and } \\
\text { Muslims }\end{array}$ & $\begin{array}{l}\text { No. of } \\
\text { obs. }\end{array}$ & \\
\hline $\begin{array}{c}\text { School } \\
\text { Enrollment } \\
\text { Status } \\
\end{array}$ & & 91 & & 30585 & \\
\hline $\begin{array}{l}\text { Studied } \\
\text { previously }\end{array}$ & $80 \%$ & & $88 \%$ & & \\
\hline $\begin{array}{l}\text { Presently } \\
\text { studies }\end{array}$ & $20 \%$ & & $10 \%$ & & \\
\hline Never studied & $0 \%$ & & $2 \%$ & & \\
\hline & & & & & $\begin{array}{l}\text { p-value for chi-sq test = } \\
0.003\end{array}$ \\
\hline Marital Status & & 99 & & 30585 & \\
\hline Married & $58 \%$ & & $60 \%$ & & \\
\hline Divorced & $0 \%$ & & $0 \%$ & & \\
\hline Widowed & $0 \%$ & & $0 \%$ & & \\
\hline Single & $42 \%$ & & $40 \%$ & & \\
\hline & & & & & $\begin{array}{l}\text { p-value for chi-sq test }= \\
0.930\end{array}$ \\
\hline $\begin{array}{l}\text { Labor Force } \\
\text { Status }\end{array}$ & & 60 & & 30583 & \\
\hline $\begin{array}{l}\text { Full-time } \\
\text { employment }\end{array}$ & $93 \%$ & & $64 \%$ & & \\
\hline $\begin{array}{l}\text { Part-time } \\
\text { employment }\end{array}$ & $3 \%$ & & $6 \%$ & & \\
\hline $\begin{array}{l}\text { Absent from } \\
\text { work }\end{array}$ & $0 \%$ & & $3 \%$ & & \\
\hline Unemployed & $0 \%$ & & $7 \%$ & & \\
\hline $\begin{array}{l}\text { Not part of } \\
\text { labor force }\end{array}$ & $3 \%$ & & $19 \%$ & & \\
\hline & & & & & $\begin{array}{l}\text { p-value for chi-sq test }= \\
0.000\end{array}$ \\
\hline $\begin{array}{l}\text { District of } \\
\text { Residence }\end{array}$ & & 113 & & 30585 & \\
\hline Gaza & $44 \%$ & & $22 \%$ & & \\
\hline Judea Samaria & $55 \%$ & & $78 \%$ & & \\
\hline Jerusalem & $1 \%$ & & $0 \%$ & & \\
\hline & & & & & $\begin{array}{l}p \text {-value for chi-sq test }= \\
0.000\end{array}$ \\
\hline
\end{tabular}

Chi-square test refers to a test of the null hypothesis that the characteristic is independent of PIJ status. 


\section{$\underline{\text { Table } 4.3}$}

Characteristics of Palestinian Islamic Jihad terrorists and Palestinian population of similar age, sex and religion - sample restricted: only individuals between 18-41 years of age were included, and 50 PIJ leaders deported on December 17, 1992 were not included.

\begin{tabular}{|c|c|c|c|c|c|}
\hline Characteristics & $\begin{array}{c}\text { PIJ } \\
\text { terrorists }\end{array}$ & $\begin{array}{l}\text { No. of } \\
\text { obs. }\end{array}$ & $\begin{array}{c}\text { Palestinian } \\
\text { population } \\
\text { Age } 18-41 \\
\text { Males and } \\
\text { Muslims }\end{array}$ & $\begin{array}{c}\text { No. of } \\
\text { obs. }\end{array}$ & \\
\hline Poverty & & 43 & & 16195 & \\
\hline Poor & $28 \%$ & & $32 \%$ & & \\
\hline Average & $44 \%$ & & $48 \%$ & & \\
\hline Well & $28 \%$ & & $20 \%$ & & \\
\hline \multirow[t]{2}{*}{ Very Well } & $0 \%$ & & $0 \%$ & & \\
\hline & & & & & $\begin{array}{l}\text { p-value for chi-sq test }= \\
0.666\end{array}$ \\
\hline Age & & 67 & & 30585 & \\
\hline $18-24$ & $66 \%$ & & $39 \%$ & & \\
\hline $25-31$ & $27 \%$ & & $33 \%$ & & \\
\hline $32-38$ & $7 \%$ & & $21 \%$ & & \\
\hline \multirow[t]{2}{*}{$39-41$} & $0 \%$ & & $7 \%$ & & \\
\hline & & & & & $\begin{array}{l}\text { p-value for chi-sq test }= \\
0.000\end{array}$ \\
\hline Education & & 42 & & 29954 & \\
\hline Primary school & $10 \%$ & & $19 \%$ & & \\
\hline Intermediate & $0 \%$ & & $27 \%$ & & \\
\hline Secondary & $48 \%$ & & $36 \%$ & & \\
\hline Vocational & $5 \%$ & & $1 \%$ & & \\
\hline Post-secondary & $0 \%$ & & $8 \%$ & & \\
\hline \multirow[t]{2}{*}{$\begin{array}{l}\text { Academic } \\
\text { institute }\end{array}$} & $38 \%$ & & $9 \%$ & & \\
\hline & & & & & $\begin{array}{l}\text { p-value for chi-sq test }= \\
0.000\end{array}$ \\
\hline $\begin{array}{c}\text { Residence } \\
\text { Type }\end{array}$ & & 66 & & 30585 & \\
\hline Urban & $53 \%$ & & $33 \%$ & & \\
\hline Rural & $21 \%$ & & $54 \%$ & & \\
\hline \multirow[t]{2}{*}{ Refugee camps } & $26 \%$ & & $13 \%$ & & \\
\hline & & & & & $\begin{array}{l}\text { p-value for chi-sq test }= \\
0.000\end{array}$ \\
\hline
\end{tabular}




\begin{tabular}{|c|c|c|c|c|c|}
\hline Characteristics & $\begin{array}{c}\text { PIJ } \\
\text { terrorists }\end{array}$ & $\begin{array}{l}\text { No. of } \\
\text { obs. }\end{array}$ & $\begin{array}{c}\text { Palestinian } \\
\text { population } \\
\text { Age 18-41 } \\
\text { Males and } \\
\text { Muslims }\end{array}$ & $\begin{array}{l}\text { No. of } \\
\text { obs. }\end{array}$ & \\
\hline $\begin{array}{c}\text { School } \\
\text { Enrollment } \\
\text { Status } \\
\end{array}$ & & 47 & & 30585 & \\
\hline $\begin{array}{l}\text { Studied } \\
\text { previously }\end{array}$ & $77 \%$ & & $88 \%$ & & \\
\hline $\begin{array}{l}\text { Presently } \\
\text { studies }\end{array}$ & $23 \%$ & & $10 \%$ & & \\
\hline Never studied & $0 \%$ & & $2 \%$ & & \\
\hline & & & & & $\begin{array}{l}\text { p-value for chi-sq test }= \\
0.005\end{array}$ \\
\hline Marital Status & & 50 & & 30585 & \\
\hline Married & $32 \%$ & & $60 \%$ & & \\
\hline Divorced & $0 \%$ & & $0 \%$ & & \\
\hline Widowed & $0 \%$ & & $0 \%$ & & \\
\hline Single & $68 \%$ & & $40 \%$ & & \\
\hline & & & & & $\begin{array}{l}\text { p-value for chi-sq test }= \\
0.001\end{array}$ \\
\hline $\begin{array}{l}\text { Labor Force } \\
\text { Status }\end{array}$ & & 22 & & 30583 & \\
\hline $\begin{array}{l}\text { Full-time } \\
\text { employment }\end{array}$ & $91 \%$ & & $64 \%$ & & \\
\hline $\begin{array}{l}\text { Part-time } \\
\text { employment }\end{array}$ & $9 \%$ & & $6 \%$ & & \\
\hline $\begin{array}{l}\text { Absent from } \\
\text { work }\end{array}$ & $0 \%$ & & $3 \%$ & & \\
\hline Unemployed & $0 \%$ & & $7 \%$ & & \\
\hline $\begin{array}{l}\text { Not part of } \\
\text { labor force }\end{array}$ & $0 \%$ & & $19 \%$ & & \\
\hline & & & & & $\begin{array}{l}\text { p-value for chi-sq test }= \\
0.055\end{array}$ \\
\hline $\begin{array}{l}\text { District of } \\
\text { Residence }\end{array}$ & & 64 & & 30585 & \\
\hline Gaza & $61 \%$ & & $22 \%$ & & \\
\hline Judea Samaria & $37 \%$ & & $78 \%$ & & \\
\hline Jerusalem & $2 \%$ & & $0 \%$ & & \\
\hline & & & & & $\begin{array}{l}p \text {-value for chi-sq test }= \\
0.000\end{array}$ \\
\hline
\end{tabular}

Chi-square test refers to a test of the null hypothesis that the characteristic is independent of PIJ status. 


\section{$\underline{\text { Table } 5.1}$}

Logistic Estimates of Participation in Hamas and PIJ

Dependent Variable is 1 if Individual is a Hamas or PIJ terrorist, and 0 Otherwise

Standard errors shown in Parentheses, marginal effects are presented in brackets.

\begin{tabular}{|c|c|c|c|c|c|c|}
\hline & \multicolumn{3}{|c|}{ Unweighted Estimates } & \multicolumn{3}{|c|}{ Weighted Estimates } \\
\hline & (1) & $(2)$ & $(3)$ & (4) & $(5)$ & (6) \\
\hline \multirow[t]{2}{*}{ Intercept } & $-6.079^{* * * *}$ & $-6.152^{* * *}$ & $-6.695^{* * * *}$ & $-5.763^{* * *}$ & $-5.836^{* * *}$ & $-6.348^{* * * *}$ \\
\hline & $(0.393)$ & $(0.405)$ & $(0.441)$ & $(0.361)$ & $(0.367)$ & $(0.359)$ \\
\hline \multirow[t]{3}{*}{ Education } & $0.533^{* * * *}$ & $0.519^{* * * *}$ & $0.493^{* * * *}$ & $0.531^{* * * *}$ & $0.516^{* * * *}$ & $0.489^{* * * *}$ \\
\hline & $(0.028)$ & $(0.029)$ & $(0.030)$ & $(0.035)$ & $(0.034)$ & $(0.034)$ \\
\hline & {$[0.001]$} & {$[0.001]$} & {$[0.001]$} & {$[0.001]$} & {$[0.011]$} & {$[0.001]$} \\
\hline \multirow{3}{*}{$\begin{array}{l}\text { Poverty } \\
(1=\text { yes })\end{array}$} & $-0.869^{\text {***** }}$ & $-0.928^{* * * *}$ & $-1.043^{* * * *}$ & $-0.842^{\text {****** }}$ & $-0.898^{* * * *}$ & $-1.015^{* * * *}$ \\
\hline & $(0.211)$ & $(0.213)$ & $(0.224)$ & $(0.209)$ & $(0.207)$ & $(0.220)$ \\
\hline & {$[-0.001]^{\dagger}$} & {$[-0.001]^{\dagger}$} & {$[-0.001]^{\dagger}$} & {$[-0.002]^{\dagger}$} & {$[-0.002]^{\dagger}$} & {$[-0.002]^{\dagger}$} \\
\hline \multirow[t]{3}{*}{ Age } & $-0.189^{* \cdots *}$ & $-0.191^{* \cdots *}$ & $-0.143^{\text {***** }}$ & $-0.183^{* * * * *}$ & $-0.184^{* * * *}$ & $-0.138^{\text {*氺 }}$ \\
\hline & $(0.016)$ & $(0.016)$ & $(0.020)$ & $(0.020)$ & $(0.019)$ & $(0.020)$ \\
\hline & {$[-0.000]$} & {$[-0.000]$} & {$[-0.000]$} & {$[-0.000]$} & {$[-0.000]$} & {$[-0.000]$} \\
\hline \multirow{3}{*}{$\begin{array}{l}\text { Gaza } \\
\text { (1=yes) }\end{array}$} & -- & $1.149^{* * * *}$ & $1.295^{* * *}$ & -- & $1.121^{* * *}$ & $1.253^{* * *}$ \\
\hline & & $(0.163)$ & $(0.174)$ & & $(0.162)$ & $(0.175)$ \\
\hline & & {$[0.002]^{\dagger}$} & {$[0.002]^{\dagger}$} & & {$[0.004]^{\dagger}$} & {$[0.004]^{\dagger}$} \\
\hline \multirow{2}{*}{$\begin{array}{l}\text { Married } \\
(1=\text { yes })\end{array}$} & --- & --- & $-0.926^{* \ldots *}$ & --- & --- & $-0.909^{* * * * 4}$ \\
\hline & & & $\begin{array}{c}(0.222) \\
{[0.001]^{\dagger}}\end{array}$ & & & $\begin{array}{c}(0.209) \\
{[0.002]^{\dagger}}\end{array}$ \\
\hline Pseudo R2 & 0.3612 & 0.3801 & 0.3776 & 0.3718 & 0.3906 & 0.3881 \\
\hline $\begin{array}{l}\text { Number of } \\
\text { obs. }\end{array}$ & 19810 & 19810 & 19789 & 19810 & 19810 & 19789 \\
\hline \multicolumn{7}{|c|}{$\begin{array}{l}\text { Notes: Sample size is } 42097 \text {. Sample pools together observations on Hamas and PIJ and } \\
\text { the general population from } 1993 \text { Labor Force Survey in Judea, Samaria and Gaza } \\
\text { (ICBS). Weights used in columns (4), (5) and (6) are relative share of Hamas and PIJ in } \\
\text { population to their share in the sample and relative share of survey respondents in the } \\
\text { population to their share in the sample. Weight is } 0.12566 \text { for Hamas and PIJ sample and } \\
0.080491 \text { for the survey sample. } \\
(\dagger) \text { dy/dx is for discrete change of dummy variable from } 0 \text { to } 1 . \\
(* * *) \text { significant at } 5 \% \text { significance level. } \\
(* *) \text { significant at } 10 \% \text { significance level. } \\
(*) \text { significant at } 15 \% \text { significance level. }\end{array}$} \\
\hline
\end{tabular}




\section{Table 5.2}

Logistic Estimates of Participation in Hamas and PIJ - $\underline{\text { Sample restricted not to include }}$ the 50 PIJ leaders deported on December 17, 1992.

Dependent Variable is 1 if Individual is a Hamas or PIJ terrorist, and 0 Otherwise

Standard errors shown in Parentheses, marginal effects are presented in brackets.

\begin{tabular}{|c|c|c|c|c|c|c|}
\hline & \multicolumn{3}{|c|}{ Unweighted Estimates } & \multicolumn{3}{|c|}{ Weighted Estimates } \\
\hline & $(1)$ & $(2)$ & (3) & $(4)$ & $(5)$ & $(6)$ \\
\hline \multirow[t]{2}{*}{ Intercept } & $-5.735^{* * *}$ & $-5.820^{* * *}$ & $-6.824^{* * * *}$ & $-5.414^{* * *}$ & $-5.503^{* * *}$ & $-6.461^{* * *}$ \\
\hline & $(0.445)$ & $(0.467)$ & $(0.527)$ & $(0.423)$ & $(0.441)$ & $(0.437)$ \\
\hline \multirow[t]{3}{*}{ Education } & $0.553^{* * * *}$ & $0.530^{* * * *}$ & $0.486^{* * * *}$ & $0.548^{* * * *}$ & $0.524^{* * * *}$ & $0.478^{* * *}$ \\
\hline & $(0.033)$ & $(0.033)$ & $(0.035)$ & $(0.042)$ & $(0.041)$ & $(0.041)$ \\
\hline & {$[0.000]$} & {$[0.000]$} & {$[0.000]$} & {$[0.001]$} & {$[0.001]$} & {$[0.001]$} \\
\hline \multirow{3}{*}{$\begin{array}{l}\text { Poverty } \\
\text { (1=yes) }\end{array}$} & $-0.706^{* * * *}$ & $-0.781^{* * * *}$ & $-0.923^{* * * *}$ & $-0.677^{* * *}$ & $-0.748^{* \cdots *}$ & $-0.891^{\text {*** }}$ \\
\hline & $(0.221)$ & $(0.223)$ & $(0.236)$ & $(0.218)$ & $(0.218)$ & $(0.235)$ \\
\hline & {$[-0.000]^{\dagger}$} & {$[-0.000]^{\dagger}$} & {$[-0.001]^{\dagger}$} & {$[-0.001]^{\dagger}$} & {$[-0.001]^{\dagger}$} & {$[-0.001]^{\dagger}$} \\
\hline \multirow[t]{3}{*}{ Age } & $-0.225^{* * *}$ & $-0.228^{* * *}$ & $-0.146^{* * * *}$ & $-0.217^{* * *}$ & $-0.219^{* * *}$ & $-0.138^{\text {**** }}$ \\
\hline & $(0.020)$ & $(0.020)$ & $(0.024)$ & $(0.025)$ & $(0.025)$ & $(0.026)$ \\
\hline & {$[-0.000]$} & {$[-0.000]$} & {$[-0.000]$} & {$[-0.000]$} & {$[-0.000]$} & {$[-0.000]$} \\
\hline \multirow{3}{*}{$\begin{array}{l}\text { Gaza } \\
\text { (1=yes) }\end{array}$} & --- & $1.496^{* * * *}$ & $1.802^{* * * *}$ & --- & $1.464^{* * * *}$ & $1.756^{* * * *}$ \\
\hline & & (0 181) & (0 197) & & & \\
\hline & & {$[0.002]^{\dagger}$} & {$[0.002]^{\dagger}$} & & {$[0.003]^{\dagger}$} & {$[0.004]^{\dagger}$} \\
\hline \multirow{2}{*}{$\begin{array}{l}\text { Married } \\
(1=\text { yes })\end{array}$} & --- & --- & $-1.581^{* * * *}$ & --- & --- & $-1.566^{* * * *}$ \\
\hline & & & $\begin{array}{c}(0.272) \\
{[-0.002]^{\dagger}}\end{array}$ & & & $\begin{array}{c}(0.258) \\
{[0.003]^{\dagger}}\end{array}$ \\
\hline Pseudo R2 & 0.3648 & 0.3970 & 0.4081 & 0.3749 & 0.4071 & 0.4184 \\
\hline $\begin{array}{l}\text { Number of } \\
\text { obs. }\end{array}$ & 19764 & 19764 & 19743 & 19764 & 19764 & 19743 \\
\hline \multicolumn{7}{|c|}{$\begin{array}{l}\text { Notes: Sample size is } 42097 \text {. Sample pools together observations on Hamas and PIJ and } \\
\text { the general population from } 1993 \text { Labor Force Survey in Judea, Samaria and Gaza } \\
\text { (ICBS). Weights used in columns (4), (5) and (6) are relative share of Hamas and PIJ in } \\
\text { population to their share in the sample and relative share of survey respondents in the } \\
\text { population to their share in the sample. Weight is } 0.12566 \text { for Hamas and PIJ sample and } \\
0.080491 \text { for the survey sample. } \\
\left({ }^{\dagger}\right) \text { dy/dx is for discrete change of dummy variable from } 0 \text { to } 1 . \\
(* * *) \text { significant at } 5 \% \text { significance level. } \\
(* *) \text { significant at } 10 \% \text { significance level. } \\
(*) \text { significant at } 15 \% \text { significance level. }\end{array}$} \\
\hline
\end{tabular}




\section{$\underline{\text { Table } 5.3}$}

Logistic Estimates of Participation in Hamas and PIJ - sample restricted: only individuals between 18-41 years of age were included, and the 50 PIJ leaders deported on December 17,1992 were not included.

Dependent Variable is 1 if Individual is a Hamas or PIJ terrorist, and 0 Otherwise Standard errors shown in Parentheses, marginal effects are presented in brackets.

\begin{tabular}{|c|c|c|c|c|c|c|}
\hline & \multicolumn{3}{|c|}{ Unweighted Estimates } & \multicolumn{3}{|c|}{ Weighted Estimates } \\
\hline & (1) & $(2)$ & (3) & (4) & $(5)$ & (6) \\
\hline \multirow[t]{2}{*}{ Intercept } & $-5.479^{* * * *}$ & $-5.603^{* * *}$ & $-6.878^{* * * *}$ & $-5.199^{* * * *}$ & $-5.318^{* * *}$ & $-6.562^{* * * *}$ \\
\hline & $(0.500)$ & $(0.523)$ & $(0.606)$ & $(0.463)$ & $(0.485)$ & $(0.520)$ \\
\hline \multirow[t]{3}{*}{ Education } & $0.572^{* * * *}$ & $0.547^{\text {***** }}$ & $0.502^{* * * *}$ & $0.566^{* * * *}$ & $0.540^{* * * *}$ & $0.494^{* * * *}$ \\
\hline & $(0.035)$ & $(0.035)$ & $(0.037)$ & $(0.044)$ & $(0.043)$ & $(0.043)$ \\
\hline & {$[0.001]$} & {$[0.000]$} & {$[0.000]$} & {$[0.001]$} & {$[0.001]$} & {$[0.001]$} \\
\hline \multirow{3}{*}{$\begin{array}{l}\text { Poverty } \\
\text { (1=yes) }\end{array}$} & $-0.567^{* * * * *}$ & $-0.649^{* * * *}$ & $-0.768^{* * * *}$ & $-0.536^{* * * *}$ & $-0.615^{* * * * *}$ & $-0.736^{* \cdots * 3 *}$ \\
\hline & $(0223)$ & $(0226)$ & $(0240)$ & $(0216)$ & $(0217)$ & $(0234)$ \\
\hline & {$[-0.001]^{\dagger}$} & {$[-0.000]^{\dagger}$} & {$[-0.001]^{\dagger}$} & {$[-0.001]^{\dagger}$} & {$[-0.001]^{\dagger}$} & {$[-0.001]^{\dagger}$} \\
\hline \multirow[t]{3}{*}{ Age } & $-0.247^{* * * *}$ & $-0.246^{* * * *}$ & $-0.153^{* \cdots *}$ & $-0.237^{* * * *}$ & $-0.236^{* * * *}$ & $-0.143^{\text {**** }}$ \\
\hline & $(0.022)$ & $(0.023)$ & $(0.029)$ & $(0.029)$ & $(0.028)$ & $(0.031)$ \\
\hline & {$[-0.000]$} & {$[-0.000]$} & {$[-0.000]$} & {$[-0.001]$} & {$[-0.001]$} & {$[-0.000]$} \\
\hline \multirow{3}{*}{$\begin{array}{l}\text { Gaza } \\
(1=y e s)\end{array}$} & -- & $1.435^{* * *}$ & $1.724^{* * *}$ & -- & $1.403^{* * *}$ & $1.679^{* * * *}$ \\
\hline & & $(0.187)$ & $(0.204)$ & & $(0.183)$ & $(0.197)$ \\
\hline & & {$[0.001]^{\dagger}$} & {$[0.003]^{\dagger}$} & & {$[0.005]^{\dagger}$} & {$[0.005]^{\dagger}$} \\
\hline \multirow{2}{*}{$\begin{array}{l}\text { Married } \\
(1=\text { yes })\end{array}$} & --- & --- & $-1.540^{* * * *}$ & --- & --- & $-1.533^{\text {**** }}$ \\
\hline & & & $\begin{array}{c}(0.280) \\
{[-0.002]^{\dagger}}\end{array}$ & & & $\begin{array}{c}(0.267) \\
{[-0.004]^{\dagger}}\end{array}$ \\
\hline Pseudo R2 & 0.3612 & 0.3913 & 0.4043 & 0.3705 & 0.4005 & 0.4141 \\
\hline $\begin{array}{l}\text { Number of } \\
\text { obs. }\end{array}$ & 16358 & 16358 & 16339 & 16358 & 16358 & 16339 \\
\hline \multicolumn{7}{|c|}{$\begin{array}{l}\text { Notes: Sample size is } 42097 . \text { Sample pools together observations on Hamas and PIJ and } \\
\text { the general population from } 1993 \text { Labor Force Survey in Judea, Samaria and Gaza } \\
\text { (ICBS). Weights used in columns (4), (5) and (6) are relative share of Hamas and PIJ in } \\
\text { population to their share in the sample and relative share of survey respondents in the } \\
\text { population to their share in the sample. Weight is } 0.12566 \text { for Hamas and PIJ sample and } \\
0.080491 \text { for the survey sample. } \\
\left({ }^{\dagger}\right) \text { dy/dx is for discrete change of dummy variable from } 0 \text { to } 1 . \\
(* * *) \text { significant at } 5 \% \text { significance level. } \\
(* *) \text { significant at } 10 \% \text { significance level. } \\
(*) \text { significant at } 15 \% \text { significance level. }\end{array}$} \\
\hline
\end{tabular}




\section{$\underline{\text { Table 6.1 }}$}

Logistic Estimates of being a suicide bomber

Dependent Variable is 1 if Individual is a suicide bomber, and 0 Otherwise

Standard errors shown in Parentheses, marginal effects are presented in brackets.

\begin{tabular}{|c|c|c|c|c|c|c|}
\hline & \multicolumn{3}{|c|}{ Unweighted Estimates } & \multicolumn{3}{|c|}{ Weighted Estimates } \\
\hline & (1) & $(2)$ & (3) & (4) & (5) & $(6)$ \\
\hline \multirow[t]{2}{*}{ Intercept } & $-4.781^{* * * *}$ & $-4.757^{* * *}$ & $-6.701^{* * * *}$ & $-6.804^{* * * *}$ & $-6.869^{* * * *}$ & $-8.913^{* * * *}$ \\
\hline & $(0.871)$ & $(0.915)$ & $(1.076)$ & $(0.648)$ & $(0.631)$ & $(0.752)$ \\
\hline \multirow[t]{3}{*}{ Education } & $0.746^{* * * *}$ & $0.702^{* * * *}$ & $0.659^{* * * *}$ & $0.724^{* * * 3}$ & $0.743^{* * * 3}$ & $0.707^{* * *}$ \\
\hline & $(0.070)$ & $(0.070)$ & $(0.074)$ & $(0.095)$ & $(0.084)$ & $(0.085)$ \\
\hline & {$[0.000]$} & {$[0.000]$} & {$[9.37 \mathrm{e}-06]$} & [9.22e-07] & [5.06e-07] & {$[3.42 \mathrm{e}-07]$} \\
\hline \multirow{3}{*}{$\begin{array}{l}\text { Poverty } \\
\text { (1=yes) }\end{array}$} & $-1.452^{* * *}$ & $-1.488^{* * *}$ & $-1.522^{* * *}$ & $-1.521^{* * * *}$ & $-1.631^{* * * *}$ & $-1.717^{* * *}$ \\
\hline & $(0.499)$ & $(0.501)$ & $(0.507)$ & $(0.501)$ & $(0.497)$ & $(0.507)$ \\
\hline & {$[-0.000]^{\dagger}$} & {$[-0.000]^{\dagger}$} & {$[-0.000]^{\dagger}$} & {$[-1.60 \mathrm{e}-06]^{\dagger}$} & {$[-9.11 \mathrm{e}-07]^{\dagger}$} & {$[-6.77 \mathrm{e}-07]^{\dagger}$} \\
\hline \multirow[t]{3}{*}{ Age } & $-0.436^{* * *}$ & $-0.431^{* * * *}$ & $-0.301^{* * *}$ & $-0.444^{* * *}$ & $-0.480^{* * * *}$ & $-0.351^{* * * *}$ \\
\hline & $(0.052)$ & $(0.052)$ & $(0.061)$ & $(0.069)$ & $(0.063)$ & $(0.064)$ \\
\hline & {$[-7.22 \mathrm{e}-06]$} & {$[-7.29 \mathrm{e}-06]$} & {$[-4.28 \mathrm{e}-06]$} & {$[-5.66 e-07]$} & {$[-3.27 e-07]$} & [-1.70e-07] \\
\hline \multirow{3}{*}{$\begin{array}{l}\text { Gaza } \\
\text { (1=yes) }\end{array}$} & --- & $1.605^{* * * 3 *}$ & $1.912^{* 3 * \pi}$ & --- & $1.959^{* * * *}$ & $2.445^{* * 3 *}$ \\
\hline & & $(0.365)$ & $(0.382)$ & & $(0.377)$ & $(0.394)$ \\
\hline & & {$[0.000]^{\dagger}$} & {$[0.000]^{\dagger}$} & & {$[2.83 \mathrm{e}-06]^{\dagger}$} & {$[3.15 \mathrm{e}-06]^{\dagger}$} \\
\hline \multirow{3}{*}{$\begin{array}{l}\text { Married } \\
(1=\text { yes })\end{array}$} & --- & --- & $-2.525^{* * *}$ & --- & --- & $-2.681^{\text {***** }}$ \\
\hline & & & (0 711) & & & $(0,664)$ \\
\hline & & & {$[-0.000]^{\dagger}$} & & & {$[-3.18 \mathrm{e}-06]^{\dagger}$} \\
\hline Pseudo R2 & 0.4740 & 0.5009 & 0.5240 & 0.4110 & 0.4444 & 0.4642 \\
\hline $\begin{array}{l}\text { Number of } \\
\text { obs. }\end{array}$ & 19637 & 19637 & 19635 & 19637 & 19637 & 19635 \\
\hline \multicolumn{7}{|c|}{$\begin{array}{l}\text { Notes: Sample size is } 41828 \text {. Sample pools together observations on suicide bombers and } \\
\text { the general population from } 1993 \text { Labor Force Survey in Judea, Samaria and Gaza } \\
\text { (ICBS). Weights used in columns (4), (5) and (6) are relative share of suicide bombers in } \\
\text { population to their share in the sample and relative share of survey respondents in the } \\
\text { population to their share in the sample. Weight is } 0.006338 \text { for suicide bombers sample } \\
\text { and } 0.079977 \text { for the survey sample. } \\
\left({ }^{\dagger}\right) \text { dy/dx is for discrete change of dummy variable from } 0 \text { to } 1 . \\
(* * *) \text { significant at } 5 \% \text { significance level. } \\
(* *) \text { significant at } 10 \% \text { significance level. } \\
(*) \text { significant at } 15 \% \text { significance level. }\end{array}$} \\
\hline
\end{tabular}




\section{Table 6.2}

Logistic Estimates of being a suicide bomber - sample restricted: only individuals between 17-28 years of age were included.

Dependent Variable is 1 if Individual is a suicide bomber, and 0 Otherwise

Standard errors shown in Parentheses, marginal effects are presented in brackets.

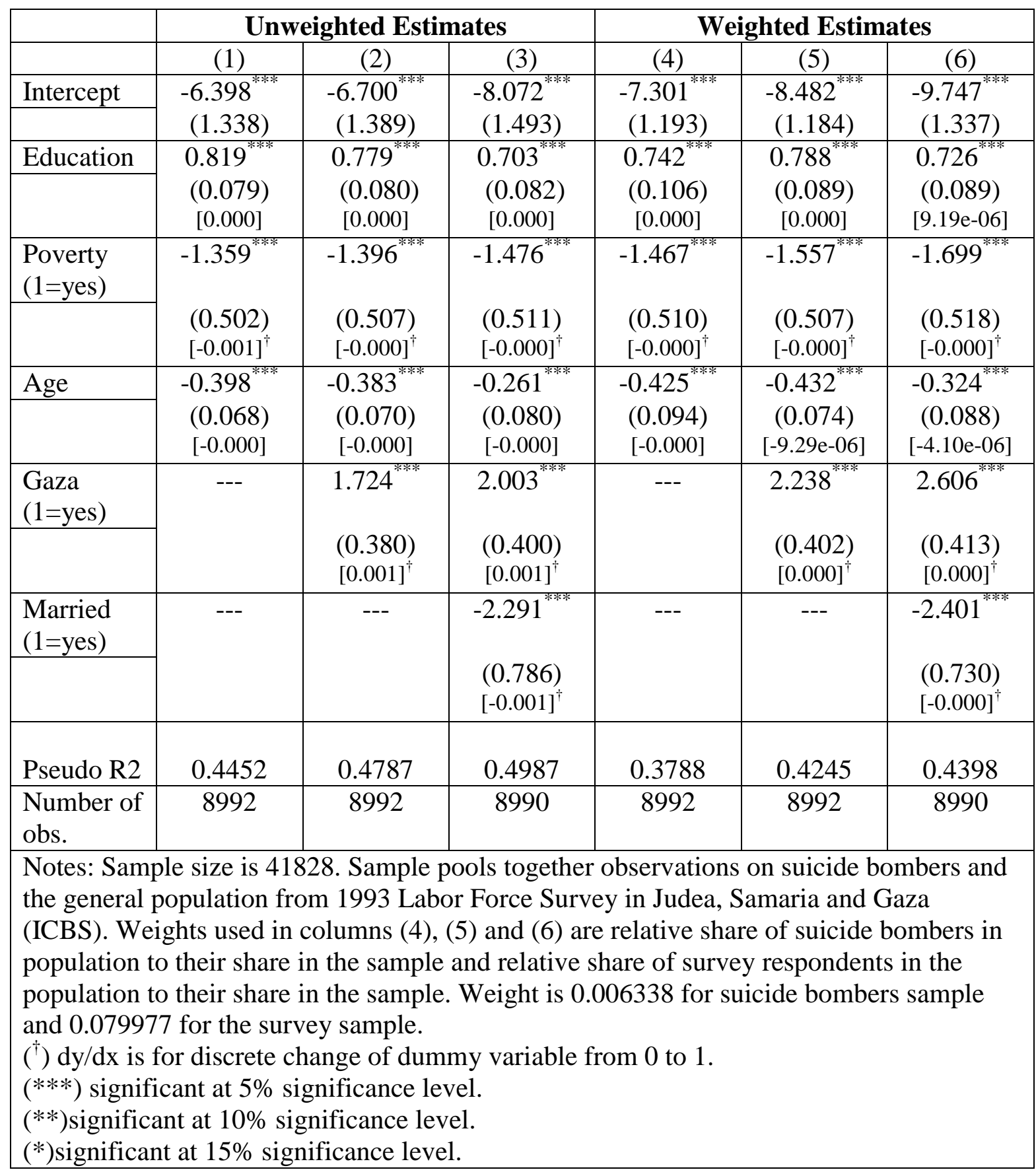




\section{$\underline{\text { Table } 7}$}

Negative binomial regression for the number of terrorists attack

Standard errors are presented in parenthesis. The economic variable of interest, in this case the logarithm of the annual average wage, was obtain from three different sources

\begin{tabular}{|c|c|c|c|c|c|c|c|c|}
\hline & (1) & (2) & (3) & (4) & $(5)$ & (6) & $(7)$ & $(8)$ \\
\hline $\begin{array}{c}\text { Log } \\
\text { (average wage) }\end{array}$ & $\begin{array}{r}0.693 \\
(1.165) \\
\end{array}$ & $\begin{array}{l}1.558^{*} \\
(0.995) \\
\end{array}$ & $\begin{array}{l}-0.891 \\
(1.235) \\
\end{array}$ & $\begin{array}{r}-0.818 \\
(0.936) \\
\end{array}$ & $\begin{array}{l}-0.033 \\
(1.024) \\
\end{array}$ & $\begin{array}{r}0.897 \\
(1.344) \\
\end{array}$ & $\begin{array}{r}0.006 \\
(1.013) \\
\end{array}$ & $\begin{array}{r}0.096 \\
(1.028) \\
\end{array}$ \\
\hline source dummy 1 & & $\begin{array}{l}0.880^{* * * *} \\
(0.321)\end{array}$ & $\begin{array}{l}-0.510 \\
(0.573) \\
\end{array}$ & $\begin{array}{c}-1.442^{* * * *} \\
(0.595)\end{array}$ & $\begin{array}{c}-1.613^{* * * *} \\
(0.580)\end{array}$ & $\begin{array}{l}0.703^{* *} \\
(0.401)\end{array}$ & $\begin{array}{c}-1.554^{* * *} \\
(0.568)\end{array}$ & $\begin{array}{c}-1.595^{\text {*** }} \\
(0.574)\end{array}$ \\
\hline source dummy 2 & & & & & & $\begin{array}{l}-0.314 \\
(0.422) \\
\end{array}$ & $\begin{array}{l}0.602^{*} \\
(0.369) \\
\end{array}$ & $\begin{array}{r}0.420 \\
(0.557) \\
\end{array}$ \\
\hline year dummy & & & $\begin{array}{l}0.075^{* * *} \\
(0.026) \\
\end{array}$ & & $\begin{array}{l}-0.075^{*} \\
(0.050) \\
\end{array}$ & & & $\begin{array}{r}-0.033 \\
(0.075) \\
\end{array}$ \\
\hline $\log ($ popsize $)$ & & & & $\begin{array}{c}2.828^{* * *} \\
(0.661)\end{array}$ & $\begin{array}{l}4.738^{* * *} \\
(1.434)\end{array}$ & & $\begin{array}{l}3.419^{* * *} \\
(0.729)\end{array}$ & $\begin{array}{l}4.072^{* * *} \\
(1.669)\end{array}$ \\
\hline constant & $\begin{array}{l}-1.330 \\
(6.706)\end{array}$ & $\begin{array}{l}-6.587 \\
(5.752)\end{array}$ & $\begin{array}{c}-141.845^{* * *} \\
(47.792)\end{array}$ & $\begin{array}{c}-13.162^{* * *} \\
(4.881)\end{array}$ & $\begin{array}{l}116.862 \\
(86.417)\end{array}$ & $\begin{array}{l}-2.644 \\
(7.880)\end{array}$ & $\begin{array}{c}-22.410^{* * *} \\
(7.294)\end{array}$ & $\begin{array}{c}36.950 \\
(136.308)\end{array}$ \\
\hline Number of obs. & 30 & 30 & 30 & 30 & 30 & 30 & 30 & 30 \\
\hline
\end{tabular}

$(* * *),(* *)$ and $(*)$ refers to the significance level at $5 \%, 10 \%$ and $15 \%$ respectively.

${ }^{1}$ Source 1- The Central Bureau of Statistics, Statistical Abstract of Israel, as published on table 3.13 in "The Economics of the West Bank and Gaza Strip", Fawzi A. Gharaibeh, Westview Press 1985. for the years 1971-1980.

Source 2- computation from the "Labor Force Surveys in Judea, Samaria and Gaza for the period 1981-1993.

Source 3- Palestinian Central Bureau of Statistics for the period 1995-2001. 


\section{Table 8}

Negative binomial regression for the number of terrorists attack.

Standard errors are presented in parenthesis. The economic variable of interest, in this case the annual GDP per capita growth rate, was obtain from two different sources .

\begin{tabular}{|c|c|c|c|c|c|c|}
\hline & (1) & (2) & (3) & (4) & $(5)$ & $(6)$ \\
\hline \multirow[t]{2}{*}{ GDP pc growth } & 0.158 & 0.315 & 0.402 & 0.460 & 0.169 & $1.048^{* * * * *}$ \\
\hline & $(0.515)$ & $(0.527)$ & $(0.569)$ & $(0.484)$ & $(0.532)$ & $(0.453)$ \\
\hline \multirow[t]{2}{*}{ source dummy } & & & & & $0.770^{* * * *}$ & $-2.123^{* * * * \pi}$ \\
\hline & & & & & $(0.286)$ & $(0.796)$ \\
\hline \multirow[t]{2}{*}{ year dummy } & & $0.029^{* * * *}$ & & $-0.071^{* *}$ & & 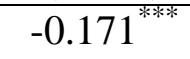 \\
\hline & & $(0.012)$ & & $(0.037)$ & & $(0.051)$ \\
\hline \multirow[t]{2}{*}{$\log ($ popsize $)$} & & & $0.952^{* * * *}$ & $2.716^{* * * *}$ & & $7.406^{* * * *}$ \\
\hline & & & $(0.302)$ & $(0.965)$ & & $(2.011)$ \\
\hline \multirow[t]{2}{*}{ constant } & $2.671^{* * *}$ & $-54.845^{* * *}$ & $-4.364^{* * * *}$ & $122.893^{* *}$ & $2.416^{* * *}$ & $288.296^{* * * *}$ \\
\hline & $(0.145)$ & $(23.434)$ & $(2.215)$ & $(66.234)$ & $(0.153)$ & $(88.152)$ \\
\hline Number of obs. & 32 & 32 & 32 & 32 & 32 & 32 \\
\hline
\end{tabular}

$(* * *),(* *)$ and $(*)$ refers to the significance level at $5 \%, 10 \%$ and $15 \%$ respectively.

${ }^{1}$ Source 1- Israel Central Bureau of Statistics for the period 1969-1992.

Source 2- The CIA world fact book for the period 1994-2001.

I did not compute the 1993 GDP per capita growth because it would assume possible comparison of the GDP levels between the two sources. 


\section{$\underline{\text { Table } 9}$}

Negative binomial regression for the number of suicide terrorists attack.

Standard errors are presented in parenthesis. The economic variable of interest, in this case the lagged logarithm of the annual GDP per capita growth, was obtain from two different sources ${ }^{4}$.

\begin{tabular}{|c|c|c|c|c|c|c|}
\hline & (1) & (2) & (3) & (4) & (5) & (6) \\
\hline $\begin{array}{c}\text { Lagged } \\
\text { (GDP pc growth) }\end{array}$ & $\begin{array}{l}0.488 \\
(0.897) \\
\end{array}$ & $\begin{array}{r}1.090 \\
(0.879) \\
\end{array}$ & $\begin{array}{l}2.151^{\text {** }} \\
(1.119)\end{array}$ & $\begin{array}{l}2.150^{* *} \\
(1.143)\end{array}$ & $\begin{array}{l}3.350^{* * *} \\
(1.361)\end{array}$ & $\begin{array}{l}3.950^{\text {*** }} \\
(1.493)\end{array}$ \\
\hline $\begin{array}{c}\text { Lag } \\
{[(\text { GDP pc gr }) * \text { wb }]}\end{array}$ & & & & & $\begin{array}{l}-2.070^{*} \\
(1.322)\end{array}$ & $\begin{array}{l}-2.716^{* *} \\
(1.444)\end{array}$ \\
\hline source dummy & & & $\begin{array}{l}-2.507 \\
(1.749)\end{array}$ & $\begin{array}{l}-2.507 \\
(1.749)\end{array}$ & $\begin{array}{l}-3.090^{* *} \\
(1.773)\end{array}$ & $\begin{array}{l}-3.421^{* *} \\
(1.766)\end{array}$ \\
\hline year dummy & & $\begin{array}{l}0.196^{* *} \\
(0.102)\end{array}$ & $\begin{array}{l}0.494^{\text {**** }} \\
(0.231)\end{array}$ & $\begin{array}{l}0.495^{\text {**** }} \\
(0.232)\end{array}$ & $\begin{array}{l}0.558^{* * * *} \\
(0.232)\end{array}$ & $\begin{array}{l}0.582^{* * * *} \\
(0.229)\end{array}$ \\
\hline wb dummy & & & & $\begin{array}{l}-0.003 \\
(0.735)\end{array}$ & & $\begin{array}{c}0.658 \\
(0.699)\end{array}$ \\
\hline constant & $\begin{array}{r}0.159 \\
(0.409) \\
\end{array}$ & $\begin{array}{l}-392.231^{* *} \\
(202.927) \\
\end{array}$ & $\begin{array}{r}-985.557^{* * *} \\
(460.920)\end{array}$ & $\begin{array}{r}-985.744^{* * * *} \\
(462.762) \\
\end{array}$ & $\begin{array}{c}-1111.711^{* * *} \\
(461.780)\end{array}$ & $\begin{array}{r}-1160.665^{\text {*** }} \\
(456.466)\end{array}$ \\
\hline Number of obs. & 22 & 22 & 22 & 22 & 22 & 22 \\
\hline
\end{tabular}

$(* * *),(* *)$ and $(*)$ refers to the significance level at $5 \%, 10 \%$ and $15 \%$ respectively.

${ }^{1}$ Source 1- Israel Central Bureau of Statistics for the period 1989-1992.

Source 2- The CIA world fact book for the period 1994-2001. 